\title{
WestVirginiaUniversity
}

THE RESEARCH REPOSITORY @ WVU

Graduate Theses, Dissertations, and Problem Reports

2009

\section{Perceptions of the Farmland Preservation Program by West Virginia farmers}

Jamey Allen Murray

West Virginia University

Follow this and additional works at: https://researchrepository.wvu.edu/etd

\section{Recommended Citation}

Murray, Jamey Allen, "Perceptions of the Farmland Preservation Program by West Virginia farmers" (2009). Graduate Theses, Dissertations, and Problem Reports. 2802.

https://researchrepository.wvu.edu/etd/2802

This Thesis is protected by copyright and/or related rights. It has been brought to you by the The Research Repository @ WVU with permission from the rights-holder(s). You are free to use this Thesis in any way that is permitted by the copyright and related rights legislation that applies to your use. For other uses you must obtain permission from the rights-holder(s) directly, unless additional rights are indicated by a Creative Commons license in the record and/ or on the work itself. This Thesis has been accepted for inclusion in WVU Graduate Theses, Dissertations, and Problem Reports collection by an authorized administrator of The Research Repository @ WVU. For more information, please contact researchrepository@mail.wvu.edu. 


\title{
Perceptions of the Farmland Preservation Program \\ by West Virginia Farmers
}

\author{
Jamey Allen Murray
}

\author{
Thesis submitted to the \\ Davis College of Agriculture, Forestry, and Consumer Sciences \\ at West Virginia University \\ in partial fulfillment of the requirements \\ for the degree of
}

\author{
Master of Science \\ in \\ Agricultural and Extension Education \\ Deborah A. Boone, Ph.D., Chair \\ Harry N. Boone, Jr., Ph.D. \\ Stacy A. Gartin, Ph.D. \\ Douglas D. LaVergne, Ph.D. \\ Division of Resource Management \\ Morgantown, West Virginia \\ 2009
}

Keywords: Agricultural Education, Agriculture, Education, Farmland Preservation 


\author{
ABSTRACT \\ Perceptions of the Farmland Preservation Program \\ by West Virginia Farmers
}

\title{
Jamey Allen Murray
}

The purpose of this study was to determine the perceptions of West Virginia Farmers towards the Farmland Preservation Program. A descriptive research design using a mailed questionnaire was used for this study. The questionnaire was sent to a random sample of 255 farmers enrolled in the Monongahela Soil Conservation District from Marion, Monongalia, and Preston counties, a 36.8\% response rate was obtained. This study found that farmers from Monongalia, Preston and Marion counties had a basic understanding of the Farmland Preservation Program and a desire to know more. The majority of the respondents were male and between the ages of 51 and 60. The farmers perceived a decrease in farmland loss and that small farms would be maintained as an impact of Farmland Preservation Programs. Only one respondent currently had their farm enrolled in farmland preservation and less than half of the respondents would consider placing their land in farmland preservation. Perceived barriers to participation included lack of knowledge, the program is perpetual and limited funding is available. Newspapers, newsletters along with public meetings and mail were the preferred methods for these landowners to receive information about Farmland Preservation Programs in their county. 


\section{DEDICATION}

I would like to take this opportunity to dedicate this thesis to all of the people who have had an influence in my life. To my parents Charles and Yvonne Murray; thanks for always loving and believing in me. To my wonderful, caring and loving wife; Amber; you were the driving force in getting this thesis done. When I felt the most like throwing in the towel you were there to give me the gentle, but loving nudge I needed. 


\section{ACKNOWLEDGEMENTS}

The completion of this thesis has come from the hard work and dedication of several people. I would like to thank and acknowledge those who helped me obtain this milestone in my life.

To my family Dad, Mom, Sherri, Rhonda and Lisa: thanks for all of your support, wisdom and laughs, without you this wouldn't have been possible.

To my friends, thanks for helping me stay on track even though it was long time coming.

To my beautiful wife, Amber, I can't say enough about the support and guidance you gave me through all of this.

To my in-laws thanks for all that you have done to help me reach this goal.

I would also like to thank my committee for staying motivated and on task.

Dr. Debby Boone: wow it has been a long time coming, but we finally made it. I want to thank you for allowing me to take my time and finish this on my schedule. You have answered all of my questions and provided the guidance and wisdom that it took to accomplish this Master's degree.

Dr. Harry Boone: I couldn't have done this without your expertise. I would still be trying to figure out how to crunch all of this data if you hadn't been there. Thanks a bunch.

Dr. Stacy Gartin: what can I say; if I hadn't met you I might have never made the career choices I have made. You also kept my college career enjoyable. I might have driven myself crazy if you hadn't shown me that it was okay to have some fun while still achieving your life goals. 


\section{TABLE OF CONTENTS}

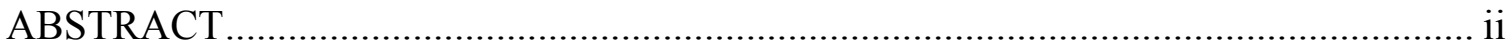

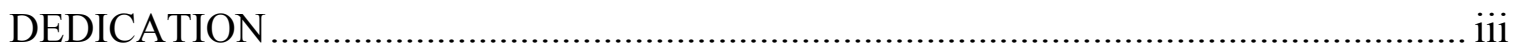

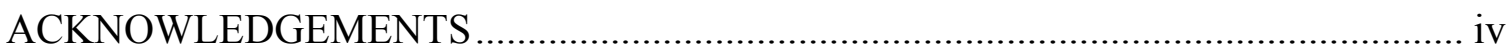

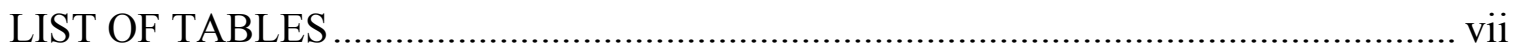

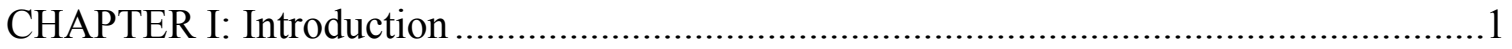

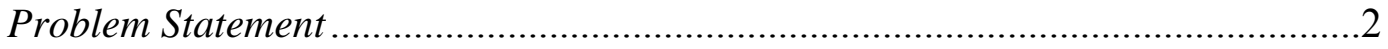

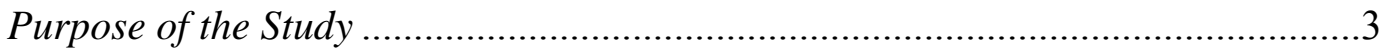

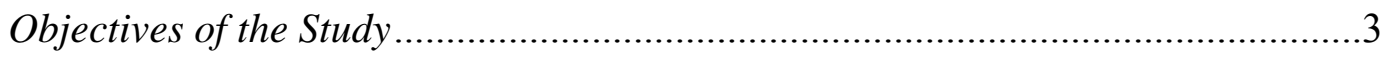

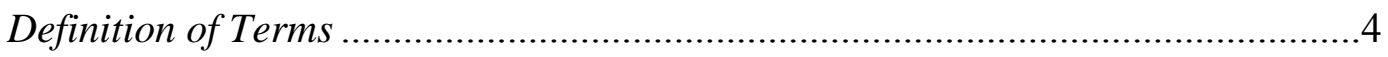

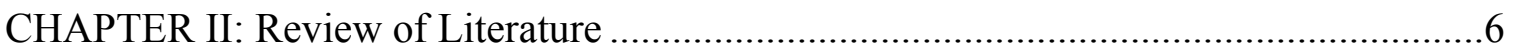

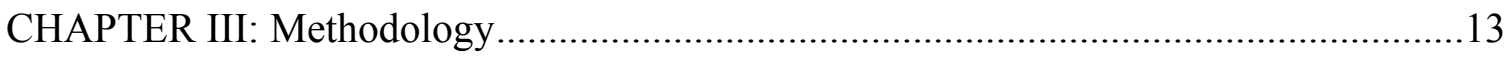

Purpose of the Study …………………………….........................................13

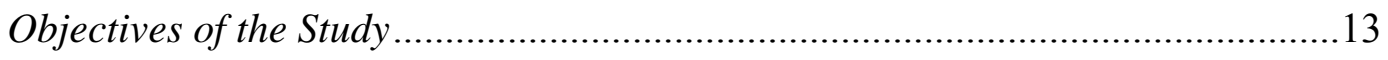

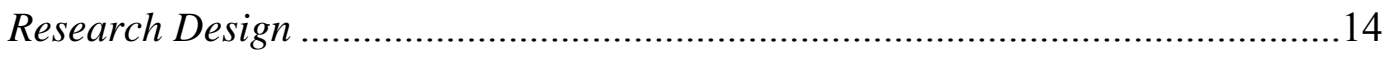

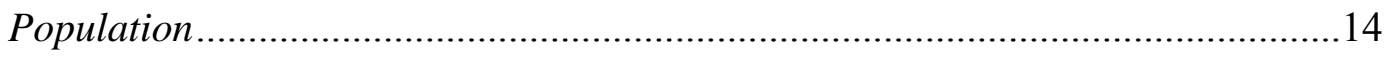

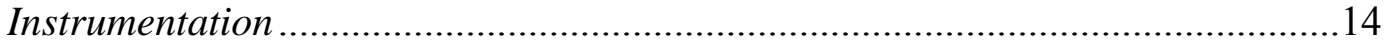

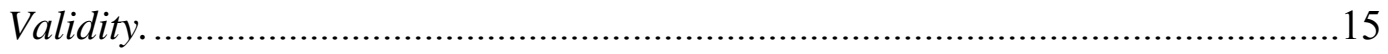

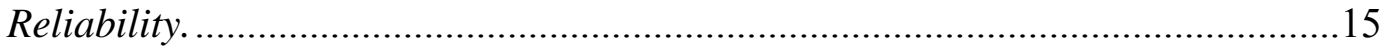

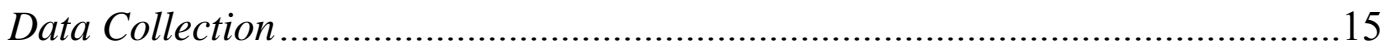

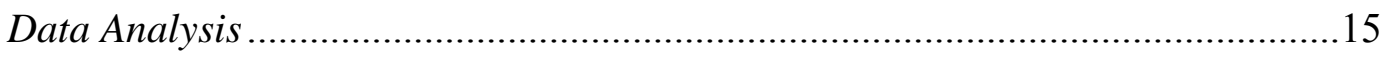

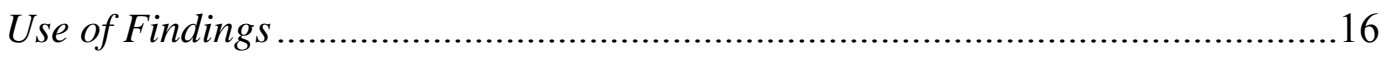

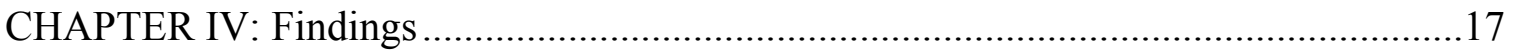

Purpose of the Study ………………..............................................................17

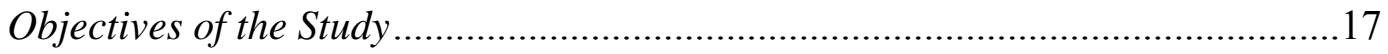

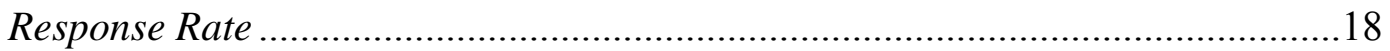

Gender and County of Respondents..............................................................18

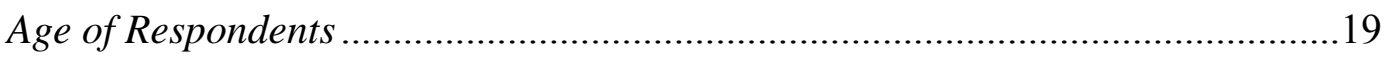

Years Farming Experience ………………………....................................20

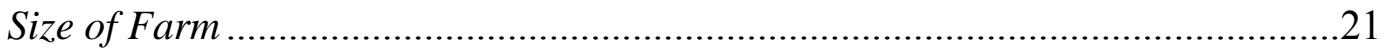

Perceptions of West Virginia Farmland Preservation Program ..........................22 
Comparison of Counties on Perceptions of the West Virginia Farmland Preservation Program ...

Farmland Preservation Program Proposed …………….....................................27

Farmland Preservation Program Implemented .....................................................28

How Long has A Farmland Preservation Program Been Implemented in your County?

Membership on the Farmland Preservation Board ...............................................30

Should a Farmland Preservation Board be Included in Your County?...................31

Are Farmers Informed about the Farmland Preservation Board?.........................32

Has the General Public Been Notified about the Farmland Preservation

Program?

Methods Desired to be Informed about the Farmland Preservation Program? ...34

Who Should Serve on a Farmland Preservation Board..........................................36

Barriers to Participating in a Farmland Preservation Board.................................38

Land Preserved in Farmland Preservation Board .................................................41

Would You Consider Placing Land in Farmland Preservation Program? ............42

Has Farmland Been Passed Down from Previous Generations?..........................43

Future of Current Farm Land .........................................................................44

CHAPTER V: Summary, Conclusions, and Recommendations ........................................46

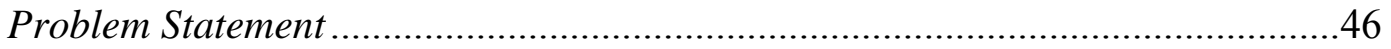

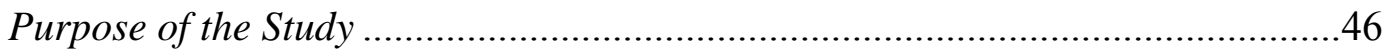

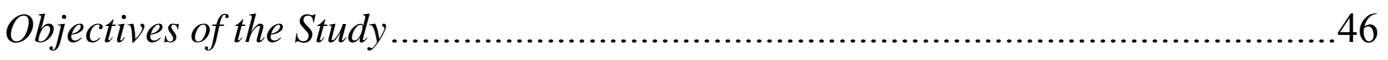

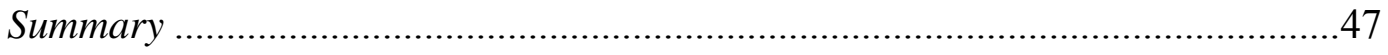

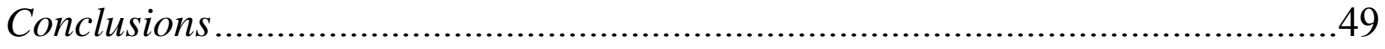

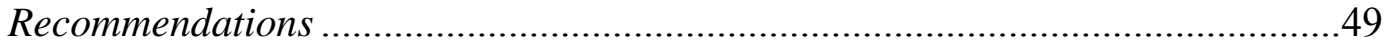

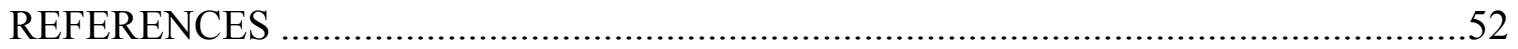

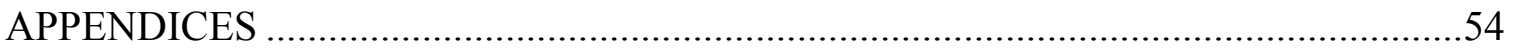

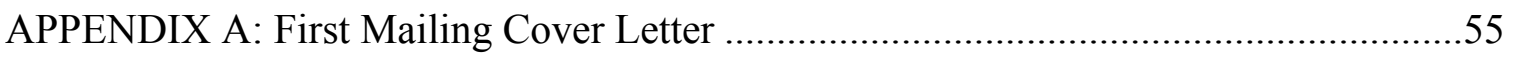

APPENDIX B: Second Mailing Cover Letter ................................................................57

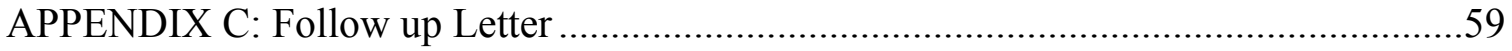

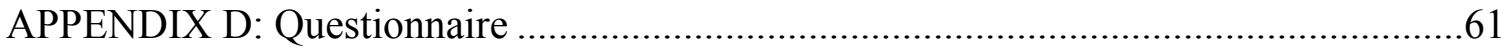

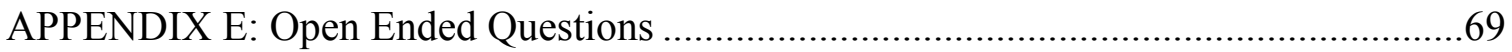

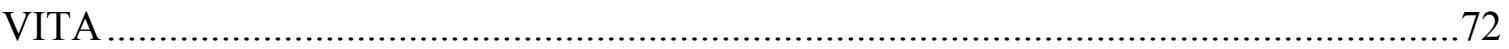




\section{LIST OF TABLES}

Table Title Page

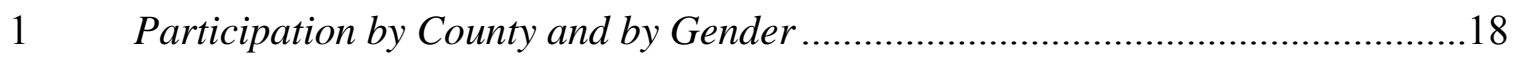

2 “Which Category Best Describes Your Age?” ..................................................19

3 "How Many Years Have You Been Farming”.....................................................20

$4 \quad$ "How Many Acres of Farmland do You Own?" ....................................................21

$5 \quad$ Farmer's Perceptions of the Farmland Preservation Program in the West Virginia Counties of Monongalia, Preston and Marion ........................................25

6 "Has a Farmland Preservation Program been Proposed for Your

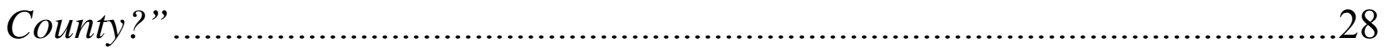

7 "Has a Farmland Preservation Program been Implemented in Your County?”.....

8 "How Long Has the Farmland Preservation Program Been Implemented

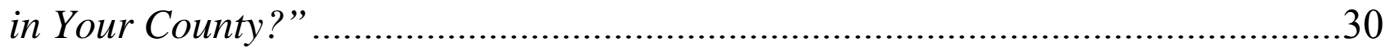

$9 \quad$ “Are You a Member of the Farmland Preservation Board?” ..................................31

10 "Do You Think a Farmland Preservation Program Should be Included in Your County?”

11 "Have Farmers within the County been Informed/Educated about the

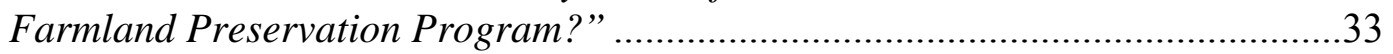

12 “Has the General Public been Notified/Educated about the Program?” ...............34

13 Methods Respondents Prefer to be Informed/Educated about Farmland Preservation Programs

14 “Who do You Think Should Serve on a Farmland Preservation Board?”.............37

15 "What are the Barriers to Participating in a Farmland Preservation Program?”

16 "What Impacts do you believe a Farmland Preservation Programs will have on your county 10 Years after Implementation"

17 "Do You Own Land that is Preserved through the Farmland Preservation Program?"

18 “Would You Consider Placing Your Land in Farmland Preservation?”.....

19 "Are You Currently Managing the same Farmland as Previous Generations of Your Family?"

20 "What do You Foresee Happening to our Farmland in the Future?" 


\section{CHAPTER I}

Introduction

The 1930's brought a new, dusty face to agriculture known as the Dust Bowl (Baumhardt, 2003). Agriculturist faced losing inches and inches of their soil to a mixture of drought and wind (Baumhardt, 2003). Today the face of agriculture is once again changing. Now farmers are losing acres, not inches, of land to two-story brick homes built to escape the noisy city pollution miles away and only creeping closer (Crider, Lembeck, \& Willits, 1991).

Not only has the growth of cities brought urban sprawl into the countryside, but so has the increase in population. According to the 2000 Census Brief, there has been a 13.2 percent increase from the 1990 United States census of 248.7 million to 281.4 million people. Population growth increased by 14 percent in the metropolitan areas alone, while land developed for urban purposes grew by 47 percent (Mackun \& Perry, 2001).

Crider et al. (1991) pointed out that the encroachment on farmland at the suburban-rural fringes is an important contributing factor to the need for protecting our farmland. In response to the need for protection of agricultural land, Congress enacted the Farmland Protection Policy Act (FPPA) as a subtitle of the 1981 Farm Bill (Fact Sheet, 2006). This act stated that:

Federal programs be compatible with state, local, and private efforts to protect farmland. For the purpose of the law, federal programs include construction projects---such as highways, airports, dams, and federal 
buildings---sponsored or financed in whole or part by the federal government, and the management of federal lands. (Fact Sheet, 2006, $\mathbb{1}$ 1)

The Natural Resources Conservation Service (NRCS) is charged with overseeing that all parts of the act are followed (Fact Sheet, 2006). The NRCS is a division of the United States Department of Agriculture, and was originally created as the Soil Conservation Service (SCS). Public Law 46 created the SCS in 1935, in response to the vast amounts of soil erosion experienced during the Dust Bowl (Helms, 2006).

Two other common practices used to protect farmland in the United States are the Purchase of Development Rights (PDR) and the Transfer of Development Rights (TDR). With the PDR, "farmers sell their development rights for cash to local entities in order to preserve their land, rather than selling their land to a developer" (Dobbs-Weir \& Dykstra, 2003, p. 13). The local entity and farmer negotiate the price based on "fair market value." This provides the farmer with a financial cushion and helps take the pressure off the farmer to sell out to a housing or commercial developer (Dobbs-Weir \& Dykstra, 2003).

The TDR program allows builders and developers to better utilize the land they have already acquired. Previous zoning policies allowed only one house per so many square feet of land, however TDR now allows a developer to build two houses where they previously could only build one (Dobbs-Weir \& Dykstra, 2003). This reduces the need for developers to purchase additional farmland for development thus saving agricultural land (Dobbs-Weir \& Dykstra, 2003).

Problem Statement

Farmland loss has been a problem ever since the days of the dust bowl. In the time period labeled the dust bowl farmland in the western plains was being lost due to 
mismanagement of the land and a severe drought. Today farmland loss is occurring across the nation because of urban sprawl, pressure from commercial developers on farmers to sell their land for nonagricultural uses, and lack of farmers taking part in the Farmland Preservation Program. There is limited research on the opinions of West Virginia farmers with regard to farmland preservation or what they perceive as potential barriers to participating in the Farmland Preservation Program.

Purpose of the Study

The purpose of the study was to determine the perceptions of farmers in West Virginia toward the Farmland Preservation Program and barriers they perceive that prevent them from enrolling their land in the program. Information obtained from this study will be used to document farmer's perceptions and knowledge of the Farmland Preservation Program and associated barriers \& benefits to participation.

\section{Objectives of the Study}

The primary objectives of the study were to determine the perceptions of West Virginia farmers toward Farmland Preservation Programs and potential barriers to participation. The specific objectives were to:

1. Determine the level of knowledge West Virginia farmers have of the Farmland Preservation Program.

2. Determine the barriers that would keep West Virginia landowners from enrolling their land in the Farmland Preservation Program.

3. Determine what West Virginia farmers perceive as benefits of the Farmland Preservation Program. 
4. Determine the level of support from farmers toward the West Virginia Farmland Preservation Program in select counties in West Virginia.

5. Determine if there is enough support from farmers to warrant the establishment of a Farmland Preservation Program in counties that have not established a program.

6. Determine whether farmers are willing to participate in a Farmland Preservation Program.

\section{Definitions of Terms}

Urban Sprawl: This includes an area of low-density development that is dispersed and uses a lot of land. It also includes geographic separation of essential places such as work, homes, schools, and shopping, and residents have almost complete dependence on automobile for travel (Anderson \& Heimlich, 2001.).

Farmland Preservation: The act of minimizing the extent to which federal activities or personal gain contribute to the unnecessary and irreversible conversion of agricultural land to nonagricultural uses (Fact Sheet, 2006).

Farmland and agriculture land: Any size tract of land used or able to be used for agriculture, grazing, or horticulture. This also includes all property designated as wetlands that are part of a property used or able to be used as farmland (West Virginia Farmland Protection Definitions, 2003).

Conservation easement: A non-possessory interest of a holder in real property, whether appurtenant or in gross, imposing limitations or affirmative obligations, the purposes of which include, but are not limited to, (a) retaining or protecting for the public benefit the natural, scenic or open-space values of real property; (b) 
assuring its availability for agricultural, forest, recreation or open-space use; (c) protecting natural resources and wildlife; (d) maintaining or enhancing land, air or water quality; and/or (e) preserving the historical, architectural or cultural aspects of real property. Conservation easements under Article 24 - Voluntary Farmland Protection Programs must be perpetual and must be held by at least one "holder." (West Virginia Farmland Protection Definitions, 2003) 


\section{CHAPTER II}

\section{Review of Literature}

America is losing acres upon acres of farmland everyday to urbanization. The West Virginia Farmland Protection website (2003) states that "from 1964-1997, the United States Department of Agriculture (USDA) reported that West Virginia lost 17,732 farms and 1,823,060 acres of farmland.”( ( 3$)$

According to Anderson and Heimlich (n.d.), "Population density in urbanized areas dropped by more than 50 percent, from 8.4 to 4 people per acre over the past 50 years " (p.2). This indicates that people are leaving urban cities and moving outside the metropolitan area or to previously rural nonmetropolitan counties (Anderson \& Heimlich, 2001.).

Two types of urban sprawl have been identified. The first type of urban sprawl is known as the urban fringe. Urban fringe is defined as:

That part of metropolitan counties that is not settled densely enough to be called urban. Low-density development of new houses, roads, and commercial buildings causes urban areas to grow farther out into the countryside, and increases the density of settlement in formerly rural areas. (Anderson \& Heimlich, 2001., p. 2)

The second type of urban sprawl is "beyond the urban fringe." This includes land developed farther out in the rural countryside. Beyond the urban fringe is the type of urban sprawl that hurts farmland the most because scattered, single family homes are placed on vast acres of previous agricultural land (Anderson \& Heimlich, 2001): 
Large lots dominate this process, and growth in large-lot development has accelerated with business cycles since 1970 . Nearly 80 percent of the acreage used for new housing construction in 1994-97 (about 2 million acres) is outside urban areas. Almost all of this land (94 percent) is in lots of 1 acre or larger, with 57 percent on lots 10 acres or larger. About 16 percent were located in existing urban areas and 5 percent were on farms. (Anderson \& Heimlich, 2001, p. 3)

There are several things that are happening to cause this rise in urban sprawl. One of the biggest reasons for the increase in people leaving the cities is simply the peacefulness and tranquility of the countryside (Anderson \& Heimlich, 2001). Anderson and Heimlich (n.d.) found that 55 percent of Americans living in medium to large cities preferred that location, but the other 45 percent wanted to live in a rural or small town setting 30 or more miles from the city. As a result of people seeking refuge in the countryside, it has increased the value of farmland and taxes of the neighboring metropolitan areas (Anderson \& Heimlich, 2001.).

There are some people who believe that urban sprawl is not as big a problem as most are trying to make it seem. Crider, Lembeck, and Willits (1991): pointed out that agricultural production is not threatened by urbanization.

Only about a third of the land urbanized in the past thirty years has been cropland or pasture and losses to urban uses were replaced by rangeland and forests. If current population and land conversion rates remain at present levels, the total amount of cropland nationwide may actually be 
larger in the future than was the case in 1980 because of new land brought into production. (Crider et al., 1991, p. 5)

Nevertheless, some argue that it is the quality of the land that is lost that is more important than sheer quantity (Crider et al., 1991).

Many fear that the loss of agricultural land may soon cause a shortage of food and fiber production for our nation and our exports to other countries (Anderson and Heimlich, n.d.). According to Anderson and Heimlich (n.d.), this is simply not a viable argument. They stated that even though the percentage of urban land in the United States has doubled since 1960, it still makes up only 3 percent of the land. That number rises to less than 5 percent in 1992 when areas developed for rural roads were included (Anderson and Heimlich, n.d.).

Another reason people feel urban sprawl poses no true threat to America's food supply is because of where most of the productive agricultural land is located. Most of America's thriving agricultural land is in the Midwest where there is simply very little developmental pressure (Crider et al., 1991).

Congress recognized the need for farmland preservation in 1981 and enacted the Farmland Protection Policy Act (FPPA) as a subtitle of the 1981 Farm Bill. The purpose of this law was to "minimize the extent to which Federal programs contribute to the unnecessary conversion of farmland to non-agricultural uses" (Fact Sheet, 2006, \ 5). The FPPA also created a public education role for the USDA. Therefore, the Natural Resource Conservation Service (NRCS), a division of the USDA, was given the role of overseeing the FPPA and to provide assistance to state and local governments and 
nonprofit organizations in the development of programs and policies to protect farmland (Fact Sheet, 2006).

On June 8, 2000, West Virginia enacted the Voluntary Farmland Protection Act. This Act "declares that agriculture is a unique life support industry and that a need exists to assist those agricultural areas of the state which are experiencing the irreversible loss of agricultural land" (West Virginia Farmland Protection, 2003). This Act also provided a two-tier system to allow landowners to voluntarily protect their farmland:

A state Land Protection Authority was established under the Department of Agriculture to accept conservation easements from landowners. In addition, the Act allows the County Commission of each county to establish a county Farmland Protection Board to develop a local protection program and to hold easements. A conservation easement offer can be made to either the state Land Protection Authority or to your local Farmland Protection Board (West Virginia farmland protection: Voluntary Farmland Protection Act, 2003, $\uparrow 1$ ).

The Farmland Protection Act provides an opportunity for the landowner to donate or offer for sale land under one of these conservation easements mentioned previously. They may do so on all or part of their property depending on regulations of local boards.

A farmer may secure protection under the Farmland Protection Program if certain eligibility requirements are met. These requirements are a point system based on land characteristics and is then placed in a conservation easement. In order for a landowner within a county to be eligible to participate in the program, they must meet the following minimum criteria: 
1. The property must be located in the county in which the Farmland Protection Board operates or application must be made to the State Authority.

2. The property shall be land which meets one or more of the following criteria, as defined by the Voluntary Farmland Protection Act of 2003:

a. used or usable for agriculture, horticulture or grazing (qualifying property)

b. wetlands that are part of the qualifying property

c. woodlands that are part of or appurtenant (whether a legal right or privilege and inherited with it) to a qualifying property tract; or held by common ownership of a person or entity owning qualifying property

3. No commercial or industrial structure shall be located on the parcel

4. Clear title to the property must be established and the application must be signed by the property owner(s) (West Virginia farmland protection background, 2003, \1).

In the Northeast, state governments have been reducing commercial pressure on farmers to sell their land through the Purchase of Development Rights. The Purchase of Development Rights helps prevent the conversion of farmland to nonagricultural uses (Kline \& Wichelns, 1994). "Nineteen states have state-level Purchase of Development Rights programs using public funds to compensate landowners for the easement on otherwise private farm or forest land (Anderson \& Heimlich, 2001., p. 4).

Although this type of purchasing has proven to be very costly and the funding may be insufficient, it has been estimated that nationwide the Purchase of Development Rights programs have cumulatively protected 819,490 acres of farmland with an expenditure of $\$ 1.2$ billion (Anderson \& Heimlich, 2001.; Kline \& Wichelns, 1994). It 
was estimated that the cost of Purchase Development Rights on cropland that is most likely subject to urban pressure over the next $30-50$ years would cost around $\$ 88-\$ 130$ billion (Anderson \& Heimlich, 2001.).

Many feel that Purchase of Development Rights is simply not worth it. On top of the tremendous cost, many feel that the Purchase of Development Rights will not remove the developmental pressures (Anderson \& Heimlich, 2001.). The Purchase of Developmental Rights is also "no guarantee that the land will be used for working agricultural enterprises" (Anderson \& Heimlich, 2001.).

A study conducted by Crider et al., 1991 found that more than 7 out of 10 citizens surveyed felt that farmland preservation should have higher priority in the years ahead. Twenty-one percent felt that the same priority was appropriate, indicating the public is aware of the need to preserve farmland (Crider et al., 1991). Wickline (2006) found that $47.8 \%$ of county commissioners in West Virginia felt there was a strong need for the citizens of their prospective counties to be educated about the Farmland Preservation Program.

Crider et al., 1991 also found that Americans not only want to continue producing food and fiber at high levels, but also want to preserve our national heritage and rural lifestyles. They also found that environmentalists and anti-growth groups see farmland preservation as a means of protecting the local environment from industrialization (Crider et al., 1991).

Americans are interested in helping preserve farmland, however limited involvement could be due to the fact that they are unaware of what action to take. According to Crider et al. (1991), there has been little research dealing specifically with 
attitudes toward the preservation of agricultural lands. This statement stands true for West Virginia. There is a need for research into farmer's knowledge and perceptions about farmland preservation in West Virginia. 


\section{CHAPTER III}

Methodology

Purpose of the Study

The purpose of the study was to determine the perceptions of farmers in West Virginia toward the Farmland Preservation Program and barriers they may perceive prevent them from enrolling their land in the program. Information obtained from this study will be used to document farmer's perceptions and knowledge of the Farmland Preservation Program and associated barriers \& benefits to participation.

\section{Objectives of the Study}

The primary objectives of the study were to determine the perceptions of West Virginia farmers toward Farmland Preservation Programs and potential barriers to participation. The specific objectives were to:

1. Determine the level of knowledge West Virginia farmers have of the Farmland Preservation Program;.

2. Determine the barriers that would keep West Virginia landowners from enrolling their land in the Farmland Preservation Program.

3. Determine what West Virginia farmers perceive as benefits of the Farmland Preservation Program.

4. Determine level of support from farmers toward the West Virginia Farmland Preservation Program in select counties in West Virginia.

5. Determine if there is enough support from farmers to warrant the establishment of a Farmland Preservation Program in counties that have not established a program. 
6. Determine whether farmers are willing to participate in a Farmland Preservation Program.

\section{Research Design}

A descriptive research design was chosen for this study. Descriptive research allows for the researcher to summarize the characteristics of different groups or to measure their attitudes and opinions toward some issue (Ary, Jacobs, Razavieh \& Sorensen, 2006).

A questionnaire was developed and used to collect the data for this study. A survey was appropriate since "surveys can be a powerful and useful tool for collecting data on human characteristics, attitudes, thoughts, and behavior” (Doyle, n.d., ๆ 6). Surveys are "a widely used method of research in sociology, business, political science, and government, as well as in education" (Ary, Jacobs, \& Razavieh, 2002, p. 374).

\section{Population}

The target population was farmers in Marion, Monongalia and Preston Counties in West Virginia. A list of farmers $(\mathrm{N}=350)$ was acquired from the Monongahela Conservation District. To gain a non-biased sample 255 names were randomly selected from the target population using the Statistical Package for the Social Sciences (SPSS) program. To ensure that selection error was avoided the list was scanned and all duplicate names were removed prior to selecting the sample population.

\section{Instrumentation}

The instrument for this study was a 31 item mailed questionnaire designed specifically for this study. The questions in the first section included Likert items about farmers' perception of the Farmland Preservation Program. The second section asked 
about whether or not a Farmland Preservation Program had been implemented in their county and for how long. The third section requested demographic information.

\section{Validity}

The instrument was presented to a panel of experts, which consisted of educators in Agricultural and Extension Education at West Virginia University as well as the local Extension Agent. Each of the experts had extensive teaching, research and/or extension experience. The selected panel of experts concluded that the instrument had face and content validity.

\section{Reliability}

The Spearman-Brown split half test was utilized to test the reliability of the instrument. The reliability of the instrument was determined to be extensive with a coefficient of .278 (Robinson, Shaver, \& Wrightsman, 1991).

\section{Data Collection}

Dillman's (2000) total design method of data collection was followed for this study. The initial packet was mailed to the randomly selected participants. The packet included a cover letter, a copy of the instrument, and a stamped self-addressed envelope. The envelopes were coded for the purpose of identifying non-respondents. The participants were given a two-week deadline in which to respond to the survey. Following the deadline for the first mailing non-respondents were mailed a second follow-up letter with duplicate copies of the materials included in the first mailing.

\section{Data Analysis}

Ninety-four surveys were returned for a response rate of $36.8 \%$. The returned instruments were recorded in an Excel spreadsheet. The data were analyzed using the 
Statistical Package for the Social Sciences. The appropriate descriptive analyses were performed and included means, frequencies and standard deviations.

To avoid non-response error early and late respondents were compared. A chisquare test of independence was performed to determine if there were any significant differences between early and late respondents. No significant differences were found between early and late respondents at $\alpha \leq .05$. According to Ary, Jacob, Razavieh and Sorensen "if no significant differences are found between early and late respondents, then the researcher can reasonably assume that the respondents represent an unbiased sample of all who received the questionnaire. The data could be pooled and generalizations made to the total sample and to the population (Ary, et. al., 2006). However, given our low response rate we will only generalize our results to the respondents.

Use of Findings

The findings of this research study will provide local governments, state governments and interested citizens the opportunity to evaluate the perceptions of West Virginia farmers and landowners toward the farmland protection program. 


\section{CHAPTER IV}

\section{Findings}

\section{Purpose of the Study}

The purpose of the study was to determine the perceptions of farmers in select West Virginia counties toward the Farmland Preservation Program and barriers they perceive that prevent them from enrolling their land in the program. Information

obtained from this study will be used to document farmer's perceptions and knowledge of the Farmland Preservation Program and associated barriers and benefits to participation. Objectives of the Study

The primary objectives of the study were to determine the perceptions of farmers in select West Virginia counties toward Farmland Preservation Programs and potential barriers to participation. The specific objectives were to:

1. Determine the level of knowledge West Virginia farmers have of the Farmland Preservation Program.

2. Determine the barriers that would keep West Virginia landowners from enrolling their land in the Farmland Preservation Program.

3. Determine what West Virginia farmers perceive as benefits of the Farmland Preservation Program.

4. Determine the level of support from farmers toward the West Virginia Farmland Preservation Program in select counties in West Virginia.

5. Determine if there is enough support from farmers to warrant the establishment of a Farmland Preservation Program in counties that have not established a program. 
6. Determine whether farmers are willing to participate in a Farmland Preservation Program.

\section{Response Rate}

The sample population $(\mathrm{N}=255)$ represented 350 farmers enrolled in the Monongahela Soil Conservation District from Marion, Monongalia, and Preston counties. A total of 94 surveys were returned for a $36.8 \%$ response rate. Of the returned surveys three $(.03 \%)$ were not useable, 47 were early respondents, and 47 were late respondents. Monongalia County had the highest rate of completed and returned surveys with 49 (52\%), while Preston County had 28 (30\%) participants and Marion County had 17 participants (18\%) complete and return their surveys.

\section{Gender and County of Respondents}

Thirty-eight (77.6\%) of the respondents from Monongalia County were males, with seven (14.3\%) females responding. Preston County had 28 respondents of which 26 $(86.7 \%)$ were males and two $(6.7 \%)$ were females. Of the respondents from Marion County, $15(83.3 \%)$ were males and three (16.7\%) were females (see Table 1).

Table 1

Participation by County and by Gender

\begin{tabular}{lcccccc}
\hline \multirow{2}{*}{ County } & \multicolumn{2}{c}{ Responses } & \multicolumn{2}{c}{ Male } & \multicolumn{2}{c}{ Female } \\
\cline { 2 - 7 } & $f$ & $\%$ & $f$ & $\%$ & $f$ & $\%$ \\
\hline Monongalia & 49 & 52 & 38 & 77.6 & 7 & 14.3 \\
Preston & 28 & 30 & 26 & 86.7 & 2 & 6.7 \\
Marion & 17 & 18 & 15 & 83.3 & 3 & 16.7 \\
\hline
\end{tabular}




\section{Age of Respondents}

The demographic data indicates that of the respondents from Monongalia County, three $(6.1 \%)$ respondents were $31-40$ years old, eight $(16.3 \%)$ respondents indicated they were $41-50$ years of age, $16(32.7 \%)$ were $51-60$ years of age, 10 respondents $(20.4 \%)$ indicated that they were $61-70$ years old, while nine (18.4\%) were 71 years of age or older (see Table 2). Of the respondents from Preston County two (6.7\%) were 21-30 years old and one (3.3\%) indicated that they were between $31-40$ years of age (see Table 2). Five (16.7\%) of the Preston County respondents indicated that they were $41-50$ years old, seven (23.3\%) were 51-60 years of age, five (16.7\%) indicated they were 61-70 years of age and nine indicated they were 71 years or older (see Table 2). Of the Marion County respondents there were two (11.1\%) that indicated that they were between the ages of 31-40 years old, three (16.7\%) indicated that they were $41-50$ years old, seven (44.4\%) were 51-60 years old, three (16.7\%) indicated that they were 61-70 years old, and two (11.1\%) were older than 71 (see Table 2).

Table 2

"Which Category Best Describes Your Age?”

\begin{tabular}{lcccccc}
\hline & \multicolumn{2}{c}{ Monongalia } & \multicolumn{2}{c}{ Preston } & \multicolumn{2}{c}{ Marion } \\
\cline { 2 - 7 } & $f$ & $\%$ & $f$ & $\%$ & $f$ & $\%$ \\
\hline 21-30 years old & 0 & 0.0 & 2 & 6.7 & 0 & 0.0 \\
31-40 years old & 3 & 6.1 & 1 & 3.3 & 2 & 11.1 \\
41-50 years old & 8 & 16.3 & 5 & 16.7 & 3 & 16.7 \\
$51-60$ years old & 16 & 32.7 & 7 & 23.3 & 7 & 44.4 \\
61-70 years old & 10 & 20.4 & 5 & 16.7 & 3 & 16.7 \\
71 or older & 9 & 18.4 & 9 & 30.0 & 2 & 11.1 \\
\hline
\end{tabular}




\section{Years Farming Experience}

When asked how many years they had been farming, $30(61.2 \%)$ respondents from Monongalia County indicated they had been farming 30 or more years, while seven people $(14.3 \%)$ indicated that they had been farming for $1-10$ years, five people $(10.2 \%)$ responded that they had been farming for 21-30 years, and three (6.1\%) people from Monongalia indicated they had farmed 11-20 years (see Table 3).

Out of the 28 people who responded from Preston County, 17 (60.7\%) indicated that they had 40 or more years experience farming. Four $(13.3 \%)$ respondents indicated they had 21-30 years farming experience, while, two (6.7\%) respondents had 11-20 years and six respondents (20\%) had 1-10 years experience farming (see Table 3).

Seven $(38.9 \%)$ respondents from Marion County had 30 or more years of farming experience. Five (27.8\%) Marion County respondents indicated they had 11-20 years to farming experience; four respondents had 21-30 years experience farming, while two (11.1\%) Marion County respondents had 1-10 years of farming experience (see Table 3).

Table 3

“How Many Years Have You Been Farming?”

\begin{tabular}{lcccccc}
\hline & \multicolumn{2}{c}{ Monongalia } & \multicolumn{2}{c}{ Preston } & \multicolumn{2}{c}{ Marion } \\
\cline { 2 - 7 } & $f$ & $\%$ & $f$ & $\%$ & $f$ & $\%$ \\
\hline $1-10$ & 7 & 14.3 & 6 & 20.0 & 2 & 11.1 \\
$11-20$ & 3 & 6.1 & 2 & 6.7 & 5 & 27.8 \\
$21-30$ & 5 & 10.2 & 4 & 13.3 & 4 & 22.2 \\
30 or more years & 30 & 61.2 & 17 & 56.7 & 7 & 38.9 \\
\hline
\end{tabular}




\section{Size of Farm}

Of the 91 respondents 47 were from Monongalia County, 27 from Preston County and 17 were from Marion County. Of the 47 respondents from Monongalia County 22 (44.9\%) indicated that they currently own more than 100 acres of farmland, nine $(18.4 \%)$ owned 51-75 acres, while six (12.2\%) people indicated they owned 1-25 and six owned 26-50 acres (see Table 4). Four (8.2\%) of the Monongalia County respondents indicated they owned 76-100 acres of farmland (see Table 4).

Preston County had 27 responses to "How many acres of farmland do you currently own." Of the 27 respondents $14(46.7 \%)$ said that they currently own 100 or more acres of farmland, five (16.7\%) indicated that they own 76-100 acres, while four (13.3\%) owned 1-25 and three (10.0\%) owned 26-50 acres. Preston County had one (3.3\%) respondent indicate they owned 51-75 acres of land (see Table 4).

Table 4

“How Many Acres of Farmland do You Own?"

\begin{tabular}{lrrrrrr}
\hline & \multicolumn{2}{c}{ Monongalia } & \multicolumn{2}{c}{ Preston } & \multicolumn{2}{c}{ Marion } \\
\cline { 2 - 7 } & $f$ & $\%$ & $f$ & $\%$ & $f$ & $\%$ \\
\hline $1-25$ & 6 & 12.2 & 4 & 13.3 & 1 & 5.6 \\
$26-50$ & 6 & 12.2 & 3 & 10.0 & 4 & 22.2 \\
$51-75$ & 9 & 18.4 & 1 & 3.3 & 3 & 16.7 \\
$76-100$ & 4 & 8.2 & 5 & 16.7 & 1 & 5.6 \\
100 or more & 22 & 44.9 & 14 & 46.7 & 8 & 44.4 \\
\hline
\end{tabular}

Eight (44.4\%) Marion County respondents indicated they own more than 100 acres of land, while four $(22.2 \%)$ own $26-50$ acres and three $(16.7 \%)$ indicated they own 
51-75 acres. One (5.6\%) indicated they owned 1-25 acres of farmland and one (5.6\%) owned 76-100 acres of farmland (see Table 4).

Perceptions of the West Virginia Farmland Preservation Program

To obtain farmers' perceptions of the Farmland Preservation program in the West Virginia counties of Monongalia, Preston and Marion, a series of 12 questions were asked that pertained to their perceptions of the farmland protection program. The questions were measured on a Likert scale with responses from 6 "Strongly Agree", 5 "Moderately Agree", 4 "Agree Slightly", 3 "Disagree Slightly", 2 "Moderately Disagree", to 1 "Strongly Disagree."

In response to the statement, "The loss of farmland in my county is a concern" 57 (62.0\%) of the 92 respondents "Strongly Agreed," 20 (21.7\%) "Moderately Agreed." Twelve (13.0\%) “Agreed Slightly," one (1.1\%) "Disagreed Slightly", one (1.1\%) respondent "Moderately Disagreed" and one (1.1\%) "Strongly Disagreed"(see Table 5).

Respondents were asked to respond to the statement "The preservation of farmland is important in my county." Ninety participants responded to this question of those, 58 (64.4\%) "Strongly Agreed", 19 (21.1\%) "Moderately Agreed", 12 (13.3\%) “Agreed Slightly", and one (1.1\%) person "Disagreed Slightly" (see Table 5).

Participants responded to the statement "A Farmland Preservation Program will decrease the loss of farmland in my county" as follows, 23 (27.4\%) "Strongly Agreed." Twenty six (31.0\%) “Moderately Agreed”, 24 (28.6\%) “Agreed Slightly", and three (3.6\%) people "Disagreed Slightly", one (1.2\%) "Moderately Disagreed" and seven (8.3\%) "Strongly Disagreed" (see Table 5). 
When given the following statement "I support the concept of a Farmland Preservation Program in my county." Forty three (49.4\%) "Strongly Agreed", 21 (24.1\%) "Moderately Agreed", 13 (14.9\%) “Agreed Slightly", two (2.3\%) people "Disagreed Slightly", three (3.4\%) "Moderately Disagreed" and five (5.7\%) "Strongly Disagreed" (see Table 5).

Respondents reacted to the statement "All citizens of my county should be educated on the benefits of the Farmland Preservation Program" in the following manner. Fifty nine (64.1\%) "Strongly Agreed," 18 (19.6\%) "Moderately Agreed," 11 (12.0\%) “Agreed Slightly," one (1.1\%) person "Disagreed Slightly," one (1.1\%) “Moderately Disagreed" and two (2.2\%) "Strongly Disagreed" (see Table 5).

The statement "A Farmland Preservation Program will have a negative impact on my county" was answered by the recipients as followed. Three (3.3\%) "Strongly Agreed," five (5.5\%) "Moderately Agreed," 12 (13.2\%) “Agreed Slightly," 16 (17.6\%) "Disagreed Slightly," 19 (20.9\%) "Moderately Disagreed" and 36 (39.6\%) "Strongly Disagreed" (see Table 5).

When asked to respond to the following statement "A Farmland Preservation Program will provide a good opportunity for landowners in my county.” Twenty four (27.0\%) "Strongly Agreed," 23 (25.8\%) "Moderately Agreed," 30 (33.7\%) "Agreed Slightly," seven (7.9\%) "Disagreed Slightly," two (2.2\%) “Moderately Disagreed" and three (3.4\%) "Strongly Disagreed" (see Table 5).

The participants were asked to respond to the following statement "A Farmland Preservation Program should be forever" 25 (27.2\%) "Strongly Agreed," 25 (27.2\%) "Moderately Agreed," 13 (14.1\%) "Agreed Slightly," nine (9.8\%) "Disagreed Slightly," 
12 (13.0\%) "Moderately Disagreed" and eight (8.7\%) "Strongly Disagreed" (see Table $5)$.

When asked if "The real estate transfer tax is beneficial to my county" 14 (19.2\%) "Strongly Agreed," 20 (27.4\%) "Moderately Agreed," 20 (27.4\%) “Agreed Slightly." Six (8.2\%) "Disagreed Slightly," 5 (6.8\%) "Moderately Disagreed" and eight (11.0\%) "Strongly Disagreed" (see Table 5). Twenty-eight (35.4\%) respondents "Strongly Agreed," 17 (21.5\%) "Moderately Agreed," 19 (24.1\%) "Agreed Slightly," seven (8.9\%) "Disagreed Slightly," and eight (10.1\%) "Strongly Disagreed" to the statement "The real estate transfer tax should be used to fund Farmland Preservation Programs." (see Table $5)$.

The participants answered the following statement "I would consider including my personal land in a Farmland Preservation Program" as follows: 13 (16.0\%) "Strongly Agreed”, 21 (25.9\%) "Moderately Agreed”, 21 (25.9\%) “Agreed Slightly”, six (7.4\%) "Disagreed Slightly", seven (8.6\%) "Moderately Disagreed" and 13 (16.0\%) "Strongly Disagreed" (see Table 5).

Seventy-seven participants responded to the following statement "If a Farmland Preservation Program is implemented in my county, the overall tax base will not be affected." Of those 15 (19.05) "Strongly Agreed", 12 (15.6\%) "Moderately Agreed", 18 (23.4\%) "Agreed Slightly", 14 (18.2\%) "Disagreed Slightly", 10 (13.0\%) "Moderately Disagreed" and eight (10.4\%) "Strongly Disagreed" (see Table 5). 
Table 5

Farmer's Perceptions of the Farmland Preservation Program in the West Virginia Counties of Monongalia, Preston and Marion

\begin{tabular}{|c|c|c|c|c|c|c|c|c|c|c|c|c|}
\hline & \multicolumn{2}{|c|}{$\begin{array}{l}\text { Strongly } \\
\text { Disagree }\end{array}$} & \multicolumn{2}{|c|}{$\begin{array}{l}\text { Moderately } \\
\text { Disagree }\end{array}$} & \multicolumn{2}{|c|}{$\begin{array}{l}\text { Disagree } \\
\text { Slightly }\end{array}$} & \multicolumn{2}{|c|}{ Agree Slightly } & \multicolumn{2}{|c|}{$\begin{array}{l}\text { Moderately } \\
\text { Agree }\end{array}$} & \multicolumn{2}{|c|}{ Strongly Agree } \\
\hline & $f$ & $\%$ & $f$ & $\%$ & $f$ & $\%$ & $f$ & $\%$ & $f$ & $\%$ & $f$ & $\%$ \\
\hline $\begin{array}{l}\text { The loss of farmland in my county } \\
\text { is a concern. }\end{array}$ & 1 & 1.1 & 1 & 1.1 & 1 & 1.1 & 12 & 13.0 & 20 & 21.7 & 57 & 62.0 \\
\hline $\begin{array}{l}\text { The preservation of farmland is } \\
\text { important in my county. }\end{array}$ & 0 & .0 & 0 & .0 & 1 & 1.1 & 12 & 13.3 & 19 & 21.1 & 58 & 64.4 \\
\hline $\begin{array}{l}\text { A Farmland Preservation Program } \\
\text { will decrease the loss of farmland } \\
\text { in my county. }\end{array}$ & 7 & 8.3 & 1 & 1.2 & 3 & 3.6 & 24 & 28.6 & 26 & 31.0 & 23 & 27.4 \\
\hline $\begin{array}{l}\text { I support the concept of a Farmland } \\
\text { Preservation Program in my county. }\end{array}$ & 5 & 5.7 & 3 & 3.4 & 2 & 2.3 & 13 & 14.9 & 21 & 24.1 & 43 & 49.4 \\
\hline $\begin{array}{l}\text { All citizens of my county should be } \\
\text { educated on the benefits of the } \\
\text { Farmland Preservation Program. }\end{array}$ & 2 & 2.2 & 1 & 1.1 & 1 & 1.1 & 11 & 12.0 & 18 & 19.6 & 59 & 64.1 \\
\hline $\begin{array}{l}\text { A Farmland Preservation Program } \\
\text { will have a negative impact on my } \\
\text { county. }\end{array}$ & 36 & 39.6 & 19 & 20.9 & 16 & 17.6 & 12 & 13.2 & 5 & 5.5 & 3 & 3.3 \\
\hline
\end{tabular}


Table 5 (Continued)

Farmer's Perceptions of the Farmland Preservation Program in the West Virginia Counties of Monongalia, Preston and Marion

\begin{tabular}{|c|c|c|c|c|c|c|c|c|c|c|c|c|}
\hline & \multicolumn{2}{|c|}{$\begin{array}{l}\text { Strongly } \\
\text { Disagree }\end{array}$} & \multicolumn{2}{|c|}{$\begin{array}{l}\text { Moderately } \\
\text { Disagree }\end{array}$} & \multicolumn{2}{|c|}{$\begin{array}{l}\text { Disagree } \\
\text { Slightly }\end{array}$} & \multicolumn{2}{|c|}{ Agree Slightly } & \multicolumn{2}{|c|}{$\begin{array}{l}\text { Moderately } \\
\text { Agree }\end{array}$} & \multicolumn{2}{|c|}{ Strongly Agree } \\
\hline & $f$ & $\%$ & $f$ & $\%$ & $f$ & $\%$ & $f$ & $\%$ & $f$ & $\%$ & $f$ & $\%$ \\
\hline $\begin{array}{l}\text { A Farmland Preservation Program } \\
\text { will provide a good opportunity for } \\
\text { landowners in my county. }\end{array}$ & 3 & 3.4 & 2 & 2.2 & 7 & 7.9 & 30 & 33.7 & 23 & 25.8 & 24 & 27.0 \\
\hline $\begin{array}{l}\text { A Farmland Preservation Program } \\
\text { should be forever. }\end{array}$ & 8 & 8.7 & 12 & 13.0 & 9 & 9.8 & 13 & 14.1 & 25 & 27.2 & 25 & 27.2 \\
\hline $\begin{array}{l}\text { The real estate transfer tax is } \\
\text { beneficial to my county. }\end{array}$ & 8 & 11.0 & 5 & 6.8 & 6 & 8.2 & 20 & 27.4 & 20 & 27.4 & 14 & 19.2 \\
\hline $\begin{array}{l}\text { The real estate transfer tax should } \\
\text { be used to fund Farmland } \\
\text { Preservation Programs. }\end{array}$ & 8 & 10.1 & 0 & .0 & 7 & 8.9 & 19 & 24.1 & 17 & 21.5 & 28 & 35.4 \\
\hline $\begin{array}{l}\text { I would consider including my } \\
\text { personal land in a Farmland } \\
\text { Preservation Program. }\end{array}$ & 13 & 16.0 & 7 & 8.6 & 6 & 7.4 & 21 & 25.9 & 21 & 25.9 & 13 & 16.0 \\
\hline $\begin{array}{l}\text { If a Farmland Preservation Program } \\
\text { is implemented in my county, the } \\
\text { overall tax base will not be } \\
\text { affected. }\end{array}$ & 8 & 10.4 & 10 & 13.0 & 14 & 18.2 & 18 & 23.4 & 12 & 15.6 & 15 & 19.5 \\
\hline
\end{tabular}


Comparison of Counties on Perceptions of the West Virginia Farmland Preservation

Program

A series of chi-square measure of association statistical procedures were calculated to determine if differences exited between the three counties on the 12 items. In each analysis, more than $25 \%$ of the cells contained five or fewer subjects. This violated the assumptions of the chi-square procedure and made the results inaccurate. Because of this issue it was impossible to determine if differences existed between counties on the 12 statements.

\section{Farmland Preservation Program Proposed}

When asked if a Farmland Preservation Program had been proposed for their county, $22(44.9 \%)$ of the 49 respondents from Monongalia County, indicated that a Farmland Preservation Program had been proposed for their county, while one $(2.0 \%)$ said no Farmland Preservation Program had been proposed. Twenty-one (42.9\%) respondents were unsure and five (10.2\%) did not respond. Nine $(32.1 \%)$ of the 28 respondents from Preston County indicated a Farmland Preservation Program had been proposed for Preston County. Nineteen individuals (63.3\%) were unsure and two (6.7\%) did not respond. Six (35.3\%) of the 17 respondents from Marion County indicated that there has been a Farmland Preservation Program proposed for their county, while three $(17.6 \%)$ respondents indicated that no farmland protection program has been proposed for their county. Nine respondents $(50.0 \%)$ were unsure (see Table 6$)$. 
Table 6

“Has a Farmland Preservation Program been Proposed for Your County?”

\begin{tabular}{lcccccccc}
\hline & \multicolumn{2}{c}{ Yes } & \multicolumn{2}{c}{ No } & \multicolumn{2}{c}{ Not Sure } & \multicolumn{2}{c}{ Missing } \\
\cline { 2 - 8 } & $f$ & $\%$ & $f$ & $\%$ & $f$ & $\%$ & $f$ & $\%$ \\
\hline Monongalia & 22 & 22 & 1 & 2.0 & 21 & 42.9 & 5 & 10.2 \\
Preston & 9 & 9 & 0 & 0.0 & 19 & 63.3 & 2 & 6.7 \\
Marion & 6 & 6 & 3 & 17.6 & 9 & 50.0 & 0 & 0.0 \\
\hline
\end{tabular}

Farmland Preservation Program Implemented

Participants from Monongalia, Preston, and Marion counties in West Virginia were asked "has a Farmland Preservation Program been implemented in your county?" Of those 31 respondents from Monongalia County, only 17 replied to this question. One (2.0\%) indicated that a Farmland Preservation Program had been implemented in Monongalia County. Sixteen (32.7\%) respondents to the question indicated that a Farmland Preservation Program had not been implemented in Monongalia County. Fourteen respondents (28.6\%) were unsure and 18 (36.7\%) failed to answer the question. Eight (26.7\%) of the 11 Preston County participants responding to this question indicated that the program had been implemented in their county, and three $(10.0 \%)$ indicated that the program had not been implemented. Six respondents $(20.0 \%)$ were unsure and 13 (43.3\%) did not respond. Marion County had four participants respond to this question; of those one $(5.6 \%)$ respondent indicated that a Farmland Preservation Program had been implemented in Marion County, while three (16.7\%) respondents indicated that no Farmland Preservation Program had been implemented in Marion County. Seven respondents (38.9\%) were unsure and seven did not respond (see Table 7). 
Table 7

“Has a Farmland Preservation Program been Implemented in Your County?”

\begin{tabular}{lcccccccc}
\hline & \multicolumn{2}{c}{ Yes } & \multicolumn{2}{c}{ No } & \multicolumn{2}{c}{ Not Sure } & \multicolumn{2}{c}{ Missing } \\
\cline { 2 - 8 } & $f$ & $\%$ & $f$ & $\%$ & $f$ & $\%$ & $f$ & $\%$ \\
\hline Monongalia & 1 & 2.0 & 16 & 32.7 & 14 & 28.6 & 18 & 36.7 \\
Preston & 8 & 26.7 & 3 & 10.0 & 6 & 20.0 & 13 & 43.3 \\
Marion & 1 & 5.6 & 3 & 16.7 & 7 & 38.9 & 7 & 38.9 \\
\hline
\end{tabular}

How Long has A Farmland Preservation Program Been Implemented in your County?

When asked to answer the question "How long has the Farmland Preservation Program been implemented in your county?" Eleven participants from Monongalia County responded to the question. Of those respondents, $11(22.4 \%)$ indicated that the Farmland Preservation Program had been implemented for 6 or more years, five (10.2\%) respondents indicated the program had been implemented for less than one year. Twenty three $(46.9 \%)$ respondents did not answer the question. In Preston County 14 responses were given for this question. Eight (26.7\%) of the respondents indicated that the program had been in place for more than six years, while three (10.0\%) respondents indicated 1-2 years, one (3.3\%) respondent replied less than one year. One (3.3\%) respondent indicated that the program had been implemented for two to three years and one (3.3\%) respondent indicated that Farmland Preservation Program in Preston County had been implemented for three to four years. Twelve respondents (40.0\%) did not answer the question. Of the five respondents from Marion County one (5.6\%) indicated that the Farmland Preservation Program had been implemented in Marion County for 4-5 years, while four Marion County respondents indicated that the Farmland Preservation Program 
had been implemented for 6 or more years. Ten $(55.6 \%)$ respondents did not answer the question (see Table 8).

Table 8

“How Long Has the Farmland Preservation Program Been Implemented in Your County?”

\begin{tabular}{lcccccc}
\hline & \multicolumn{2}{c}{ Monongalia } & \multicolumn{2}{c}{ Preston } & \multicolumn{2}{c}{ Marion } \\
\cline { 2 - 6 } & $f$ & $\%$ & $f$ & $\%$ & $f$ & $\%$ \\
\hline Less than 1 year & 5 & 10.2 & 1 & 3.3 & 0 & 0.0 \\
1-2 years & 0 & 0.0 & 3 & 10.0 & 0 & 0.0 \\
2-3 years & 0 & 0.0 & 1 & 3.3 & 0 & 0.0 \\
3-4 years & 0 & 0.0 & 1 & 3.3 & 0 & 0.0 \\
4-5 years & 0 & 0.0 & 0 & 0.0 & 1 & 5.6 \\
6 or more years & 11 & 22.4 & 8 & 26.7 & 4 & 22.2 \\
Missing & 23 & 46.9 & 12 & 40.0 & 10 & 55.6 \\
\hline
\end{tabular}

\section{Membership on the Farmland Preservation Board}

When asked "are you a member of the farmland preservation board" Monongalia County had 32 participants respond to the question. One person $(2.0 \%)$ indicated that they were a member of the farmland preservation board, while 31 respondents $(63.3 \%)$ indicated that they did not belong to the farmland preservation board. Seventeen answers (34.7\%) were missing. The $18(60.0 \%)$ respondents from Preston County all indicated they were not members of the farmland preservation board. Twelve individuals $(40.0 \%)$ from Preston County did not respond. All 10 (55.6\%) Marion County respondents to this question indicated that they were not a member of the farmland preservation board in 
Marion County. Eight participants (44.4\%) from Marion County did not respond (see Table 9).

Table 9

“Are You a Member of the Farmland Preservation Board?"

\begin{tabular}{lcccccc}
\hline & \multicolumn{2}{c}{ Yes } & \multicolumn{2}{c}{ No } & \multicolumn{2}{c}{ Missing } \\
\cline { 2 - 7 } & $f$ & $\%$ & $f$ & $\%$ & $f$ & $\%$ \\
\hline Monongalia & 1 & 2.0 & 31 & 63.3 & 17 & 34.7 \\
Preston & 0 & 0.0 & 18 & 60.0 & 12 & 40.0 \\
Marion & 0 & 0.0 & 10 & 55.6 & 8 & 44.4 \\
\hline
\end{tabular}

Should a Farmland Preservation Program be Included in Your County?

Eighty-four farmers responded to the question "Do you think a Farmland Preservation Program should be included in your county?" Thirty-five (71.4\%) of the 42 respondents from Monongalia County indicated that yes there should be a Farmland Preservation Program in their county, while seven (14.3\%) responded there should not be a Farmland Preservation Program in Monongalia County. Seven individuals (14.3\%) did not respond. In Preston County 26 people responded with, 23 (76.77\%) indicating there should be a Farmland Preservation Program in Preston County and three (10.0\%) indicated there should not be a farmland protection program in Preston County. Four individuals (13.3\%) did not respond. Marion County had $16(88.9 \%)$ respondents to this question. All respondents indicated that they felt that there should be a farmland protection program in their county. Two individuals $(11.1 \%)$ did not respond (see Table 10). 
Table 10

“Do You Think a Farmland Preservation Program Should be Included in Your County?”

\begin{tabular}{lrrrrrr}
\hline & \multicolumn{2}{c}{ Yes } & \multicolumn{2}{c}{ No } & \multicolumn{2}{c}{ Missing } \\
\cline { 2 - 7 } & $f$ & $\%$ & $f$ & $\%$ & $f$ & $\%$ \\
\hline Monongalia & 35 & 71.4 & 7 & 14.3 & 7 & 14.3 \\
Preston & 23 & 76.7 & 3 & 10.0 & 4 & 13.3 \\
Marion & 16 & 88.9 & 0 & 0.0 & 2 & 11.1 \\
\hline
\end{tabular}

Are Farmers Informed about the Farmland Preservation Program?

When asked, "Have farmers within the county been informed/educated about the Farmland Preservation Program" 54 recipients responded. Of those respondents 27 were from Monongalia County. Twelve respondents (24.5\%) indicating that the farmers of their county had been informed. Fifteen respondents $(30.6 \%)$ felt that the farmers of Monongalia County had not been informed about the Farmland Preservation Program. Nineteen individuals (38.8\%) were unsure and three individuals $(6.7 \%)$ did not respond. There were 15 respondents to this question from Preston County. Seven (23.3\%) indicated they felt farmers had been educated and eight $(26.7 \%)$ said the farmers had not been educated about farmland preservation in Preston County. Fifteen respondents (50.0\%) were unsure. Eight respondents (44.4\%) were unsure and one (5.5\%) did not respond. Marion County had nine participants respond, five $(27.8 \%)$ indicated that farmers of Marion County had been informed and educated, while four respondents $(22.2 \%)$ indicated that farmers of Marion County had not been informed or educated (see Table 11). 
Table 11

"Have Farmers within the County been Informed/Educated about the Farmland Preservation Program?”

\begin{tabular}{lcccccccc}
\hline & \multicolumn{2}{c}{ Yes } & \multicolumn{2}{c}{ No } & \multicolumn{2}{c}{ Not Sure } & \multicolumn{2}{c}{ Missing } \\
\cline { 2 - 8 } & $f$ & $\%$ & $f$ & $\%$ & $f$ & $\%$ & $f$ & $\%$ \\
\hline Monongalia & 12 & 24.5 & 15 & 30.6 & 3 & 6.1 & 19 & 38.8 \\
Preston & 7 & 23.3 & 8 & 26.7 & 0 & 0.0 & 15 & 50.0 \\
Marion & 5 & 27.8 & 4 & 22.2 & 1 & 5.6 & 8 & 44.4 \\
\hline
\end{tabular}

Has the General Public been Notified about the Farmland Preservation Program?

When asked if the general public had been notified/educated about the farmland protection program the respondents from Monongalia County; three $(6.1 \%)$ indicted that yes the general public had been notified/educated, $22(44.4 \%)$ indicated no the general public had not been notified/educated. Twenty one respondents $(42.9 \%)$ indicated that they were not sure if the general public had been notified/educated. Three individuals $(6.6 \%)$ did not respond. Four (13.3\%) respondents from Preston County indicated that the general public had been notified/educated, $10(33.3 \%)$ responded that the general public had not been notified/educated, while $16(53.3 \%)$ indicated that they weren't sure. Marion County had two (11.1\%) respondents respond that the general public had been notified/educated about the farmland protection program, while six $(33.3 \%)$ indicated that the general public had not been notified/educated. Nine (50.0\%) were not sure, and one individual (5.6\%) did not respond (see Table 12). 
Table 12

“Has the General Public been Notified/Educated about the Program?”

\begin{tabular}{lrrrrrrrr}
\hline & \multicolumn{2}{c}{ Yes } & \multicolumn{2}{c}{ No } & \multicolumn{2}{c}{ Not Sure } & \multicolumn{2}{c}{ Missing } \\
\cline { 2 - 8 } & $f$ & $\%$ & $f$ & $\%$ & $f$ & $\%$ & $f$ & $\%$ \\
\hline Monongalia & 3 & 6.1 & 22 & 44.9 & 21 & 42.9 & 3 & 6.1 \\
Preston & 4 & 13.3 & 10 & 33.3 & 16 & 53.3 & 0 & 0.0 \\
Marion & 2 & 11.1 & 6 & 33.3 & 9 & 50.0 & 1 & 5.6 \\
\hline
\end{tabular}

Methods Desired to be Informed about the Farmland Preservation Program?

When asked to select all of the methods they would like to be informed about the advantages and disadvantages of the Farmland Preservation Program 38 (79.2\%) of the respondents from Monongalia County indicated that they would want to be informed by newspaper, $36(75.0 \%)$ indicated public meetings is how they wanted to be informed, 34 (70.8\%) wanted to be informed by newsletter, 28 (58.3\%) wanted to be informed by mail, $22(45.8 \%)$ wanted to be informed by radio, $19(39.6 \%)$ preferred to be informed by television, $17(35.4 \%)$ respondents want to be informed by one-on-one conversations, six (12.5\%) want to be informed via the internet, and four $(8.3 \%)$ want to be informed by email.

The Preston County respondents want to be informed as follows, 25 (89.3\%) wanted to informed by newsletter, $23(82.1 \%)$ wanted to be informed by newsletter, 21 (75.0) wanted to be informed by newspaper, 20 (71.4\%) chose mail as how they wanted to be informed, $15(53.6 \%)$ of the respondents indicated that they wanted to be informed by one-on-one conversations, $14(50.0 \%)$ respondents wanted to be informed by radio, eight $(28.6 \%)$ indicated that they wanted to be informed by television, seven $(25.0 \%)$ 
respondents wanted to be informed by email, and one $(3.6 \%)$ wanted to be informed by something other than what we had as an option (see Appendix E)

Thirteen (72.2\%) respondents from Marion County wanted to be informed by newspaper, thirteen $(72.2 \%)$ wanted to be informed by newsletter, $11(61.1 \%)$ wanted to be informed by public meetings, 10 (55.6\%) respondents wanted to be informed by mail, nine $(50.0 \%)$ wanted to be informed by television, seven $(38.9 \%)$ wanted to be informed by one-on-one conversations, five $(27.8 \%)$ wanted to be informed by radio, four $(22.2 \%)$ wanted to be informed by email, and two $(11.1 \%)$ wanted to be informed via the internet (see Table 13).

Table 13

Methods Respondents Prefer to be Informed/Educated about Farmland Preservation Programs

\begin{tabular}{lcccccccc}
\hline & \multicolumn{2}{c}{ Monongalia } & \multicolumn{2}{c}{ Preston } & \multicolumn{2}{c}{ Marion } & \multicolumn{2}{c}{ Total } \\
\cline { 2 - 8 } & $f$ & $\%$ & $f$ & $\%$ & $f$ & $\%$ & $f$ & $\%$ \\
\hline Television & 19 & 39.6 & 8 & 28.6 & 9 & 50.0 & 36 & 38.3 \\
Radio & 22 & 45.8 & 14 & 50.0 & 5 & 27.8 & 41 & 43.6 \\
Newspaper & 38 & 79.2 & 21 & 75.0 & 13 & 72.2 & 72 & 76.6 \\
Public Meetings & 36 & 75.0 & 23 & 82.1 & 11 & 61.1 & 70 & 74.5 \\
Mail & 28 & 58.3 & 20 & 71.4 & 10 & 55.6 & 58 & 61.7 \\
Newsletter & 34 & 70.8 & 25 & 89.3 & 13 & 72.2 & 72 & 76.6 \\
Internet & 6 & 12.5 & 0 & 0.0 & 2 & 11.1 & 8 & 8.5 \\
Email & 4 & 8.3 & 7 & 25.0 & 4 & 22.2 & 15 & 16.0 \\
One on one & & & & & & & & \\
conversations & 17 & 35.4 & 15 & 53.6 & 7 & 38.9 & 39 & 41.5 \\
Other & 0 & 0.0 & 1 & 3.6 & 0 & 0.0 & 1 & 1.1 \\
\hline
\end{tabular}




\section{Who Should Serve on a Farmland Preservation Board?}

When asked "Who do you think should serve on a farmland preservation board" $45(91.8 \%)$ of the 49 respondents from Monongalia County indicated that they thought that farmers/landowners should be on the preservation board, 28 (57.1\%) indicated that they would chose Extension agents to be on the preservation board. Twenty seven (55.1\%) respondents indicated that farm bureau members and soil conservationists should be on the preservation board. Eighteen (36.7\%) indicated that county commissioners should be on the preservation board, and nine respondents (18.4\%) chose other (see Appendix E). Seven respondents (14.3\%) indicated that lawyers should be on the preservation board, six (12.2\%) indicated that surveyors should be on the preservation board, while three respondents indicated that they would want judges on the preservation board (see Table 14).

All of the $30(100.0 \%)$ respondents from Preston County indicated that they thought that farmers/landowners should be on the preservation board, $22(73.3 \%)$ indicated that soil conservationists should be on the preservation board, 21 (70.0\%) indicated that they would chose Extension agents to be on the preservation board, 16 (53.3\%) indicated that county commissioners should be on the preservation board, 15 (50.0\%) respondents indicated that farm bureau members and soil conservationists should be on the preservation board, nine (30.0\%) indicated that lawyers should be on the preservation board. Four respondents (13.3\%) indicated that they would want surveyors on the preservation board, while one respondent (3.3\%) indicated there were others they would want on the preservation board (see Appendix E). Three of the $30(10.3 \%)$ 
respondents indicated that they would want judges on the preservation board (see Table 14).

Table 14

"Who do You Think Should Serve on a Farmland Preservation Board? "

\begin{tabular}{lcccccccc}
\hline & \multicolumn{2}{c}{ Monongalia } & \multicolumn{2}{c}{ Preston } & \multicolumn{2}{c}{ Marion } & \multicolumn{2}{c}{ Total } \\
\cline { 2 - 8 } & $f$ & $\%$ & $f$ & $\%$ & $f$ & $\%$ & $f$ & $\%$ \\
\hline Lawyers & 7 & 14.3 & 9 & 30.0 & 3 & 17.6 & 19 & 19.8 \\
$\begin{array}{l}\text { County } \\
\text { Commissioners }\end{array}$ & 18 & 36.7 & 16 & 53.3 & 7 & 38.9 & 41 & 42.3 \\
Judges & 3 & 6.1 & 3 & 10.3 & 3 & 17.6 & 9 & 9.5 \\
Surveyors & 6 & 12.2 & 4 & 13.3 & 3 & 16.7 & 13 & 13.4 \\
Extension Agents & 28 & 57.1 & 21 & 70.0 & 12 & 66.7 & 61 & 62.9 \\
Farmers- & & & & & & & & \\
Landowners & 45 & 91.8 & 30 & 100.0 & 16 & 88.9 & 91 & 93.8 \\
Farm Bureau & & & & & & & & \\
Members & 27 & 55.1 & 15 & 50.0 & 13 & 72.2 & 55 & 56.7 \\
$\begin{array}{l}\text { Soil } \\
\text { Conservationist }\end{array}$ & 27 & 55.1 & 22 & 73.3 & 10 & 55.6 & 59 & 60.8 \\
Other & 9 & 18.4 & 1 & 3.3 & 0 & 0.0 & 10 & 10.3 \\
\hline
\end{tabular}

Marion County had 18 participants answer this question, of those $16(88.9 \%)$ felt that farmers/landowners should comprise the farmland preservation board, $13(72.2 \%)$ indicated that they would choose farm bureau members to be on the board, $12(66.7 \%)$ indicated that they would want extension agents on the board, and $10(55.6 \%)$ wanted soil conservationists to be on the board. Seven (38.9\%) indicated that they would want county commissioners on the board, and three (16.7\%) indicated that they would choose 
surveyors. Of the seventeen respondents three (17.6\%) chose lawyers, and three (17.6\%) indicated that they would want judges on the farmland preservation board (see Table 14). Barriers to Participating in a Farmland Preservation Board

Participants were asked, "What are the barriers to participating in a Farmland Preservation Program?" Twenty eight (57.1\%) people from Monongalia County indicated that a lack of knowledge was the main barrier, 24 (49.0\%) felt that the program being forever was a major barrier, 21 (42.9\%) indicated that funding being limited was a major barrier, 17 (34.7\%) indicated that an increase in real estate transfer tax was a barrier, $16(32.7 \%)$ felt that a lack of interest was a barrier, $13(26.5 \%)$ chose an increase in property taxes as a barrier and nine (18.3\%) indicated a barrier other than the ones listed. Five respondents (10.4\%) indicated that the length of the application process was a barrier (see Table 15).

Nineteen (65.5\%) participants from Preston County indicated that a lack of knowledge was the major barrier to participating in a Farmland Preservation Program, 18 (64.3\%) respondents chose limited funding to be a barrier, 14 (48.3\%) indicated that a lack of interest was a barrier, $13(44.8 \%)$ indicated that the program being forever was a barrier, $10(34.5 \%)$ indicated that the increase in property taxes was a major barrier, and $10(34.5 \%)$ participants indicated that an increase in the real-estate transfer tax was a barrier. Seven (24.1\%) respondents chose the length of the application process to be a barrier, while six (20.7\%) indicated that there were barriers other than the ones listed (see Table 15).

Ten (55.6\%) participants from Marion County indicated that a lack of knowledge as a barrier to participating in a Farmland Preservation Program, nine (50.0\%) indicated that increases in property taxes was a barrier to participating in a Farmland Preservation Program, and nine $(50.0 \%)$ chose the program being forever as a barrier. Six (33.3\%) 
respondents indicated both limited funding and increases in real estate transfer tax as being barriers, one respondent (5.6\%) indicated that the length of the application process is a barrier, while one respondent (5.6\%) indicated that there were barriers that were not on the list (see Appendix E) (see Table 15).

Table 15

"What are the Barriers to Participating in a Farmland Preservation Program?"

\begin{tabular}{lcccccccc}
\hline & \multicolumn{2}{c}{ Monongalia } & \multicolumn{2}{c}{ Preston } & \multicolumn{2}{c}{ Marion } & \multicolumn{2}{c}{ Total } \\
\cline { 2 - 9 } & $f$ & $\%$ & $f$ & $\%$ & $f$ & $\%$ & $f$ & $\%$ \\
\hline $\begin{array}{l}\text { Increases in property } \\
\text { taxes }\end{array}$ & 13 & 26.5 & 10 & 34.5 & 9 & 50.0 & 32 & 33.3 \\
Program is forever & 24 & 49.0 & 13 & 44.8 & 9 & 50.0 & 46 & 47.9 \\
$\begin{array}{l}\text { Application process is } \\
\text { time consuming }\end{array}$ & 5 & 10.4 & 7 & 24.1 & 1 & 5.6 & 13 & 13.7 \\
$\begin{array}{l}\text { Funding for the } \\
\text { program is limited }\end{array}$ & 21 & 42.9 & 18 & 64.3 & 6 & 33.3 & 45 & 47.4 \\
Lack of Interest & 16 & 32.7 & 14 & 48.3 & 3 & 17.6 & 33 & 34.7 \\
$\begin{array}{l}\text { Increases in real estate } \\
\text { transfer tax }\end{array}$ & 17 & 34.7 & 10 & 34.5 & 6 & 33.3 & 33 & 34.4 \\
Lack of knowledge & 28 & 57.1 & 19 & 65.5 & 10 & 55.6 & 57 & 59.4 \\
Other & 9 & 18.3 & 6 & 20.7 & 1 & 5.6 & 16 & 16.7 \\
\hline
\end{tabular}

Participants were asked "What impacts do you believe a Farmland Preservation Program will have on your county 10 years after implementation?” Thirty-two (65.3\%) respondents from Monongalia County indicated that decreased farm loss would be an impact from a Farmland Preservation Program being implemented in their county. In Monongalia County 27 (55.1\%) respondents felt that small farms would be maintained, 
20 respondents (40.8\%) felt that there would be an increase in the real estate transfer tax, and $15(30.6 \%)$ respondents indicated that there would be an increase in property taxes. Fifteen (30.6\%) respondents believed that the agriculture industry would be stronger; four (8.2\%) respondents believed that urban expansions would be controlled, and 26 (53.1\%) respondents indicated reasons that weren't on the list.

Eighteen respondents from Preston County (60.0\%) felt there would be a decrease in farmland loss, while $15(50.0 \%)$ respondents felt that small farms would be maintained. Of the respondents from Preston County 13 (43.3\%) indicated that agriculture would be stronger, 11 (36.7\%) respondents thought there would be an increase in property taxes and another $11(36.7 \%)$ respondents indicated there would be an increase in the real estate transfer tax. Four respondents (13.3\%) felt that urban expansion would be controlled, while 10 (33.4\%) respondents indicated there were other impacts than those listed on the survey.

Eleven (61.1\%) respondents from Marion County indicated that they felt there would be a decrease in farmland loss, while another $11(61.1 \%)$ respondents felt that small farms would be maintained. Marion County had seven (38.9\%) respondents who felt there would be an increase in property taxes and seven (38.9\%) respondents who felt there would be an increase in the real estate transfer taxes. Five (29.4\%) respondents thought agriculture in their county would be stronger. Three (16.7\%) of the respondents indicated that urban expansion would be controlled. Marion County had 10 (58.3\%) respondents that indicated there would be impacts other than the ones listed (see Appendix E) (see Table 16). 
Table 16

"What Impacts do you believe a Farmland Preservation Programs will have on your county 10 Years after Implementation”

\begin{tabular}{lcccccccc}
\hline & \multicolumn{2}{c}{ Monongalia } & \multicolumn{2}{c}{ Preston } & \multicolumn{2}{c}{ Marion } & \multicolumn{2}{c}{ Total } \\
\cline { 2 - 8 } & $f$ & $\%$ & $f$ & $\%$ & $f$ & $\%$ & $f$ & $\%$ \\
\hline Property Taxes & 15 & 30.6 & 11 & 36.7 & 7 & 38.9 & 33 & 34.0 \\
Real Estate tax & 20 & 40.8 & 11 & 36.7 & 7 & 38.9 & 38 & 39.2 \\
$\begin{array}{l}\text { Decreased } \\
\text { Farmland loss }\end{array}$ & 32 & 65.3 & 18 & 60.0 & 11 & 61.1 & 61 & 62.9 \\
$\begin{array}{l}\text { Agriculture } \\
\text { stronger }\end{array}$ & 15 & 30.6 & 13 & 43.3 & 5 & 29.4 & 33 & 34.4 \\
$\begin{array}{l}\text { Small farms } \\
\text { maintained }\end{array}$ & 27 & 55.1 & 15 & 50.0 & 11 & 61.1 & 53 & 54.6 \\
Tourism & 0 & 0.0 & 0 & 0.0 & 1 & 5.6 & 1 & 1.0 \\
$\begin{array}{l}\text { Urban } \\
\text { expansion }\end{array}$ & 4 & 8.2 & 4 & 13.3 & 3 & 16.7 & 11 & 11.3 \\
$\begin{array}{l}\text { Other } \\
\text { Thy }\end{array}$ & 26 & 53.1 & 10 & 33.4 & 10 & 58.3 & 46 & 47.8 \\
\hline
\end{tabular}

\section{Land Preserved in Farmland Preservation Program}

Participants were asked "Do you own land that is preserved through the Farmland Preservation Program?" Only one individual indicated that their land was in the Farmland Preservation Program. Forty-seven (95.9\%) respondents from Monongalia County indicated they did not own land that was preserved through farmland preservation. Twenty-eight (93.3\%) respondents from Preston County indicated that they did not own land preserved through the farmland preservation. Seventeen $(94.4 \%)$ respondents from Marion County indicated that they did not own land preserved through 
farmland preservation, while one (5.6\%) respondent indicated that they owned land that was preserved through the Farmland Preservation Program (see Table 19).

Table 17

"Do You Own Land that is Preserved through the Farmland Preservation Program?"

\begin{tabular}{lcccccc}
\hline & \multicolumn{2}{c}{ Yes } & \multicolumn{2}{c}{ No } & \multicolumn{2}{c}{ Missing } \\
\cline { 2 - 7 } & $f$ & $\%$ & $f$ & $\%$ & $f$ & $\%$ \\
\hline Monongalia & 0 & 0.0 & 47 & 95.9 & 2 & 4.1 \\
Preston & 0 & 0.0 & 28 & 93.3 & 2 & 6.7 \\
Marion & 1 & 5.6 & 17 & 94.4 & 0 & 0.0 \\
\hline
\end{tabular}

Would You Consider Placing Land in Farmland Preservation Program?

When asked if they would consider placing their land in the Farmland

Preservation Program, 16 (32.7\%) respondents from Monongalia County indicated they would consider placing their land into farmland preservation, 12 said they would not consider placing their land into farmland preservation, while $19(38.8 \%)$ were not sure if they would place their land in the Farmland Preservation Program. Two individuals (4.4\%) did not respond. Thirteen (43.3\%) respondents from Preston County said they would consider placing their land into the Farmland Preservation Program, one (3.3\%) said they would not, while 14 (46.7\%) indicated they were not sure if they would place their land into the Farmland Preservation Program. Two individuals did not respond. Marion County had eight (44.4\%) respondents say they would consider placing their land in the Farmland Preservation Program, three (16.7\%) that said they would not place, while seven (38.9\%) were not sure if they would place their land in the Farmland Preservation Program (see Table 18). 
Table 18

“Would You Consider Placing Your Land in Farmland Preservation?”

\begin{tabular}{lcccccccc}
\hline & \multicolumn{2}{c}{ Yes } & \multicolumn{2}{c}{ No } & \multicolumn{2}{c}{ Not Sure } & \multicolumn{2}{c}{ Missing } \\
\cline { 2 - 8 } & $f$ & $\%$ & $f$ & $\%$ & $f$ & $\%$ & $f$ & $\%$ \\
\hline Monongalia & 16 & 32.7 & 12 & 24.5 & 19 & 38.8 & 2 & 4.1 \\
Preston & 13 & 43.3 & 1 & 3.3 & 14 & 46.7 & 2 & 6.7 \\
Marion & 8 & 44.4 & 3 & 16.7 & 7 & 38.9 & 0 & 0.0 \\
\hline
\end{tabular}

Has Farmland Been Passed Down from Previous Generations?

Participants were asked if they were currently managing the same farmland as previous generations of their family. Forty-eight participants from Monongalia County responded. Twenty-nine individuals (59.2\%) indicated that they were managing the same land as previous generations of their family had managed and $19(38.8 \%)$ said they were not managing the same land. One individual (2.0\%) did not respond. From Preston County 29 people responded with 17 (56.7\%) indicating that they were managing the same land as their ancestors, while $12(40.0 \%)$ were not. One individual (3.3\%) did not respond. Eighteen participants responded from Marion County with seven (38.9\%) indicating they were managing the same farmland as previous generations, while 11 (61.1\%) were not (see Table 19). 
Table 19

“Are You Currently Managing the same Farmland as Previous Generations of Your Family?"

\begin{tabular}{lcccccc}
\hline & \multicolumn{2}{c}{ Yes } & \multicolumn{2}{c}{ No } & \multicolumn{2}{c}{ Missing } \\
\cline { 2 - 7 } & $f$ & $\%$ & $f$ & $\%$ & $f$ & $\%$ \\
\hline Monongalia & 29 & 59.2 & 19 & 38.8 & 1 & 2.0 \\
Preston & 17 & 56.7 & 12 & 40.0 & 1 & 3.3 \\
Marion & 7 & 38.9 & 11 & 61.1 & 0 & 0.0 \\
\hline
\end{tabular}

Future of Current Farm Land

When asked what they foresaw happening to their land in the future, 54 people responded from Monongalia County. Thirty-five (71.4\%) indicated their land would be passed onto the next generation, seven (14.3\%) thought their land would be sold, five $(10.2 \%)$ felt their land would be developed for residential use, three $(6.1 \%)$ respondents indicated that something other than what was on our list of options would happen to their land (see Appendix E), two (4.1\%) indicated that their land would be developed for commercial use, while two (4.1\%) thought their land would be placed in the Farmland Preservation Program.

Of those who responded from Preston County, 19 (63.3\%) indicated they felt their land would be passed onto the next generation, and $10(33.3 \%)$ felt their land would be sold. Eight (26.7\%) indicated their land would be developed for residential use, five $(16.7 \%)$ indicated their land would be placed in farmland preservation, while two $(6.7 \%)$ respondents felt that their land would be developed for commercial use. 
Thirteen (72.2\%) Marion County respondents indicated their land would be passed onto the next generation and four $(22.2 \%)$ indicated their land would be sold. One (5.6\%) felt their land would be placed in farmland preservation, one $(5.6 \%)$ indicated their land would be developed for residential use, and one (5.6\%) felt that something other than what was on the list would be the outcome for their land (see Table 20).

Table 20

"What do You Foresee Happening to our Farmland in the Future?”

\begin{tabular}{lcccccccc}
\hline & Monongalia & \multicolumn{2}{c}{ Preston } & \multicolumn{2}{c}{ Marion } & \multicolumn{2}{c}{ Total } \\
\cline { 2 - 9 } & $f$ & $\%$ & $f$ & $\%$ & $f$ & $\%$ & $f$ & $\%$ \\
\hline $\begin{array}{l}\text { Passed on to the next } \\
\text { generation }\end{array}$ & 35 & 71.4 & 19 & 63.3 & 13 & 72.2 & 67 & 69.1 \\
$\begin{array}{l}\text { Sold } \\
\text { Placed in Farmland }\end{array}$ & 7 & 14.3 & 10 & 33.3 & 4 & 22.2 & 21 & 21.6 \\
$\begin{array}{l}\text { Preservation } \\
\begin{array}{l}\text { Developed for } \\
\text { residential use }\end{array}\end{array}$ & 2 & 4.1 & 5 & 16.7 & 1 & 5.6 & 8 & 8.2 \\
$\begin{array}{l}\text { Developed for } \\
\text { commercial use }\end{array}$ & 2 & 4.1 & 2 & 6.7 & 0 & 0.0 & 4 & 4.1 \\
\begin{tabular}{l} 
Other \\
\hline
\end{tabular} & 3 & 6.1 & 0 & 0.0 & 1 & 5.6 & 4 & 4.1 \\
\hline
\end{tabular}




\section{CHAPTER V}

Summary, Conclusion and Recommendations

\section{Problem Statement}

Farmland loss has been a problem ever since the days of the dust bowl. In the time period labeled the dust bowl farmland in the western plains was being lost due to mismanagement of the land and a severe drought. Today farmland loss is occurring across the nation because of urban sprawl, pressure from commercial developers on farmers to sell their land for nonagricultural uses, and lack of farmers taking part in the Farmland Preservation Program. There is limited research on the opinions of West Virginia farmers with regard to farmland preservation or what they perceive as potential barriers to participating in the Farmland Preservation Program.

Purpose of the Study

The purpose of the study was to determine the perceptions of farmers in West Virginia toward the Farmland Preservation Program and barriers they perceive may prevent them from enrolling their land in the program. Information obtained from this study will be used to document farmer's perceptions and knowledge of the Farmland Preservation Program and associated barriers \& benefits to participation.

\section{Objectives of the Study}

The primary objectives of the study were to determine the perceptions of West Virginia farmers toward Farmland Preservation Programs and potential barriers to participation. The specific objectives were to:

1. Determine the level of knowledge West Virginia farmers have of the Farmland Preservation Program. 
2. Determine the barriers that would keep West Virginia landowners from enrolling their land in the Farmland Preservation Program.

3. Determine what West Virginia farmers perceive as benefits of the Farmland Preservation Program.

4. Determine level of support from farmers toward the West Virginia Farmland Preservation Program in select counties in West Virginia.

5. Determine if there is enough support from farmers to warrant the establishment of a Farmland Preservation Program in counties that have not established a program.

6. Determine whether farmers are willing to participate in a Farmland Preservation Program.

\section{Summary}

Of the 94 respondents a majority all of respondents were males. Slightly less than a third of the respondents from Monongalia County were between the ages of $51 \& 60$ years old, while a third of the respondents from Preston County were 71 years old or older and slightly less than half the respondents from Marion County were 51 to 60 years old.

A majority of the respondents from Monongalia County had more than 30 years of farming experience. Over half of Preston County's respondents and nearly half of the Marion County respondents had more than 30 years of farming experience. Slightly less than half of the responding farmers in all three counties were farming more than 100 acres.

A majority of the respondents "strongly agreed" with the statements that, the loss of farmland in my county is a concern, the preservation of farmland is important in my 
county, and all citizens of my county should be educated on the benefits of the Farmland Preservation Program.

When asked to discuss whether or not Farmland Preservation Programs had been proposed in their county, there was mixed opinions. In Monongalia County slightly less than half of the respondents indicated that there had been a Farmland Preservation Program proposed in their county with slightly less than a third of the respondents indicating that there hasn't been a Farmland Preservation Program implemented in their county. Slightly more than a third of the Preston County respondents indicated that there had been a Farmland Preservation Program proposed in their county and ten percent indicated that there hasn't been a Farmland Preservation Program implemented in their county. Of the respondents from Marion County slightly more than a third indicated that there had been a Farmland Preservation Program proposed in their county while slightly less than a fifth indicated that there hasn't been a farmland program implemented in their county.

A majority of the respondents felt that a Farmland Preservation Program should be implemented in their county. Less than a third of the respondents from the three counties indicated that the farmers within their county had been informed/educated about the Farmland Preservation Program.

An overwhelming majority of the farmers who responded indicated they felt farmers-landowners should be on the farmland preservation board while less than $20 \%$ thought that lawyers should be on the farmland preservation board. Over half of the respondents felt that a lack of knowledge was the primary reason for lack of participation in the Farmland Preservation Program. Over two-thirds of respondents indicated that a 
loss of farmland would occur within 10 years of implementing a Farmland Preservation Program. Of the respondents from Monongalia County over one third stated that they would place their land in the Farmland Preservation Program. Slightly less than half of the respondents from both Preston and Marion counties indicated that they would place their land in the Farmland Preservation Program. When asked what they thought would happen to their land nearly three-fourths of the respondents indicated that their land would be passed on to the next generation.

\section{Conclusions}

The following conclusions are based on the interpretation of the data collected in this study. The majority of respondents were male and between the ages of 51 and 60 years old. A majority of the respondents indicate a Farmland Preservation Program has been proposed in their county while less than a third indicated that a Farmland Preservation Program had been implemented in their county. Respondents from all three counties expressed an interest in preserving farmland, and strongly disagreed that a Farmland Preservation Program would have a negative impact on their county.

A majority of the respondents indicated that the transfer tax should be used to fund the Farmland Preservation Program. More than one half of the respondents expressed an interest in placing their land in a Farmland Preservation Program. Residents need to speak out more when their communities are being consumed by urban sprawl.

\section{Recommendations}

The following recommendations are based on input from farmers in West Virginia counties of Monongalia, Preston and Marion who responded to the study about farmers' perception of the Farmland Preservation Program. 
1. Farmland preservation committees should conduct town hall meetings to help reach the very population that is affected by urban sprawl.

2. Farmland preservation committees need to better inform the rural population and the urban population of the effects of urban sprawl on the loss of farmland and the loss of farmland on food production.

3. It is recommended that further research be conducted to determine the effectiveness of the Farmland Preservation Program.

4. It is recommended that further research be conducted to monitor the willingness of farmers to place their land in the Farmland Preservation Program.

5. It is recommended that further research be conducted to determine if the farmers who indicated that they would place their land into the Farmland Preservation Program actually followed through.

6. It is recommended that further research be conducted to determine what the barriers were that kept the farmers that indicated that they were going to place their land in the farm land preservation program from following through.

7. It is recommended that further research be conducted to determine if the farmers who placed their land in the Farmland Preservation Program were satisfied.

8. It is recommended that further research be conducted to determine if there were any further barriers to farmers placing their land in the Farmland Preservation Program.

9. It is recommended that further research be conducted to monitor the attitudes and perceptions of West Virginia farmers to the Farmland Preservation Program. 
10. It is recommended that more frequent informative meeting be held in rural areas to inform farmers and rural Americans of the benefits of the Farmland Preservation Program.

11. It is recommended that more information be delivered by a wider variety of methods (television, radio ads etc.).

12. Farmland preservation program promoters should make a more intense effort to reach the counties that have yet proposed a Farmland Preservation Program.

13. Marion county farmland preservation committees should better inform the public of the progress of the Farmland Preservation Program some respondents thought that there had already been a proposed program when nothing has been proposed for that county.

14. Monongalia county farmland preservation committee should keep the public informed of the progress of the Farmland Preservation Program.

15. Farmers should take more initiative when seeking information about the Farmland Preservation Program. 


\section{REFERENCES}

Anderson, W.D., \& Heimlich, R.E. (2001). Development at the urban fringe and beyond impacts on agriculture and rural land. Retrieved November 6, 2006, from http://www.ers.usda.gov/publications/aer803/aer803.pdf

Baumhardt, R.L (2003). Dust bowl era. Retrieved November 1, 2006, from http://www.cprl.ars.usda.gov/wmru/pdfs/Baumhardt-Dust\%20BowlEncy\%20Water\%20Sci.pdf

Crider, D.M., Lembeck, S.M., Willits, F.K. (1991). Public attitudes toward farmland preservation in Pennsylvania: Analysis of a statewide survey, The Pennsylvania State University, University Park, Pennsylvania.

Dobbs-Weir, C., \& Dykstra, R. (2003). Approaches to farmland preservation: An American case study. Unpublished case study, University of Guelph, Guelph, Ontario, Canada.

Farmland Information Center: Fact Sheet. (2006). Farmland Information Center, Washington, D.C.

Helms, D. (2006). Natural resources conservation service brief history. Retrieved October 3, 2006, from http://www.nrcs.usda.gov/about/history/articles/briefhistory.html

History of the natural resources conservation service. (n.d.) Retrieved November 06, 2006, from http://www.id.nrcs.usda.gov/about/history.html

Kline, J., \& Wichelns D. (1994). Using referendum data to characterize public support for purchasing development rights to farmland [Electronic version]. Land Economics, 7(2), 223-233. 
Mackun, P.J., \& Perry, M.J. (2001). Population change and distribution. Retrieved October 18, 2006, from http://www.census.gov/prod/2001 pubs/c2kbr01-2.pdf West Virginia Farmland Protection: Background. (2003). Retrieved January 11, 2007, from: http://www.wvfarmlandprotection.org/backgrounds.cfm

West Virginia Farmland Protection: Definitions. (2003.). Retrieved January 11, 2007, from http://www.wvfarmlandprotection.org/definitions.cfm

West Virginia Farmland Protection: The voluntary farmland protection act. (2003.). Retrieved January 11, 2007, from http://www.wvfarmlandprotection.org/acts_vfpa_summary.cfm

Wickline, T. (2006). Attitudes of County Commissioners toward farmland preservation in West Virginia. Unpublished master's thesis, West Virginia University. 
APPENDICES 
APPENDIX A

First Mailing Cover Letter 
April 11, 2007

Dear Farmer:

The substantial loss of agricultural land nationwide has influenced the development of a Farmland Preservation Program. The features of the program can be adopted on a county by county basis. As a result of my interest in agriculture and the ability of this program to provide an opportunity for landowners to protect farmland from development, I am interested in gathering additional information and insight into the knowledge, attitudes and perceptions of West Virginia farmers towards the Farmland Preservation Program. This information will be a valuable asset to localities considering the adoption of the program in their areas.

The purpose of the research is to determine farmers' perceptions toward the Farmland Preservation Program in West Virginia. The results of the study will be used to prepare a thesis partially fulfilling the requirements for a Master of Science Degree in Agricultural and Extension Education. Determining the attitudes and perceptions of West Virginia farmers can provide an insight into the issues and barriers faced by counties with regard to the implementation of a Farmland Preservation Program. Participation in this research study is completely voluntary and all information will be held as confidential as possible.

Your response to the survey will be critical to the success of the study and will only take a few minutes of your time. You may skip any question you do not comfortable answering. Survey results will be reported in a summary format and individual responses will not be identified. You will notice a code number at the top left of the return envelope. This code will be used to identify non-respondents for follow-up and will be destroyed before the data are analyzed.

Please complete the questionnaire, place it in the enclosed postage-paid self addressed return envelope, and drop it in the mail by April 24, 2007. Thank you in advance for your assistance in this research effort. We sincerely appreciate your time and effort.

Sincerely,

Jamey A. Murray

Graduate Student
Deborah A. Boone, Ph.D.

Assistant Professor 
APPENDIX B

Second Mailing Cover Letter 
April 27, 2007

\section{Dear Farmer:}

On April 11, 2007 we mailed you a questionnaire about the West Virginia Farmland Preservation Program. As of today, we have not received your reply. Your response is crucial to the success of this research effort. It is essential that your attitudes be represented in the results. If you returned the first questionnaire, thank you, there is no need to complete a second one. If you have not completed the survey, please take a few minutes to complete the enclosed survey. Please complete and return it in the self-addressed, postage paid envelope, even if you have limited or no knowledge of this program.

The substantial loss of agricultural land nationwide has influenced the development of a Farmland Preservation Program. The features of the program can be adopted on a county by county basis. As a result of my interest in agriculture and the ability of this program to provide an opportunity for landowners to protect farmland from development, I am interested in gathering additional information and insight into the knowledge, attitudes and perceptions of West Virginia farmers towards the Farmland Preservation Program. This information will be a valuable asset to localities considering the adoption of the program in their areas.

The purpose of the research is to determine farmers' perceptions toward the Farmland Preservation Program in West Virginia. The results of the study will be used to prepare a thesis partially fulfilling the requirements for a Master of Science Degree in Agricultural and Extension Education. Determining the attitudes and perceptions of West Virginia farmers can provide an insight into the issues and barriers faced by counties with regard to the implementation of a Farmland Preservation Program. Participation in this research study is completely voluntary and all information will be held as confidential as possible.

Your response to the survey will be critical to the success of the study and will only take a few minutes of your time. You may skip any question you do not comfortable answering.

Survey results will be reported in a summary format and individual responses will not be identified. You will notice a code number at the top left of the return envelope. This code will be used to identify non-respondents for follow-up and will be destroyed before the data are analyzed.

Please complete the questionnaire, place it in the enclosed postage-paid self addressed return envelope, and drop it in the mail by May 9, 2007. Thank you in advance for your assistance in this research effort. We sincerely appreciate your time and effort.

Sincerely,

Jamey A. Murray

Graduate Student
Deborah A. Boone, Ph.D.

Assistant Professor 
APPENDIX C

Follow-Up Letter 
April 25, 2007

Dear Farmer:

On April 11, 2007 we mailed you a questionnaire about the West Virginia Farmland Preservation Program. As of today, we have not received your reply. Your response is crucial to the success of this research effort. It is essential that your attitudes be represented in the results. If you returned the first questionnaire, thank you, there is no need to complete a second one. If you have not completed the survey, please take a few minutes to complete the enclosed survey. Please complete and return it in the self-addressed, postage paid envelope, even if you have limited or no knowledge of this program.

The substantial loss of agricultural land nationwide has influenced the development of a Farmland Preservation Program. The features of the program can be adopted on a county by county basis. As a result of my interest in agriculture and the ability of this program to provide an opportunity for landowners to protect farmland from development, I am interested in gathering additional information and insight into the knowledge, attitudes and perceptions of West Virginia farmers towards the Farmland Preservation Program. This information will be a valuable asset to localities considering the adoption of the program in their areas.

The purpose of the research is to determine farmers' perceptions toward the Farmland Preservation Program in West Virginia. The results of the study will be used to prepare a thesis partially fulfilling the requirements for a Master of Science Degree in Agricultural and Extension Education. Determining the attitudes and perceptions of West Virginia farmers can provide an insight into the issues and barriers faced by counties with regard to the implementation of a Farmland Preservation Program. Participation in this research study is completely voluntary and all information will be held as confidential as possible. Your response to the survey will be critical to the success of the study and will only take a few minutes of your time. You may skip any question you do not comfortable answering. Survey results will be reported in a summary format and individual responses will not be identified.

You will notice a code number at the top left of the return envelope. This code will be used to identify non-respondents for follow-up and will be destroyed before the data is analyzed.

Please complete the questionnaire, place it in the enclosed postage-paid self addressed return envelope, and drop it in the mail by May 9, 2007. Thank you in advance for your assistance in this research effort. We sincerely appreciate your time and effort.

Sincerely,

Jamey A. Murray

Graduate Student
Deborah A. Boone, Ph.D.

Assistant Professor 
APPENDIX D

Questionnaire 


\section{Perceptions of the Farmland Preservation Program by West Virginia Farmers}

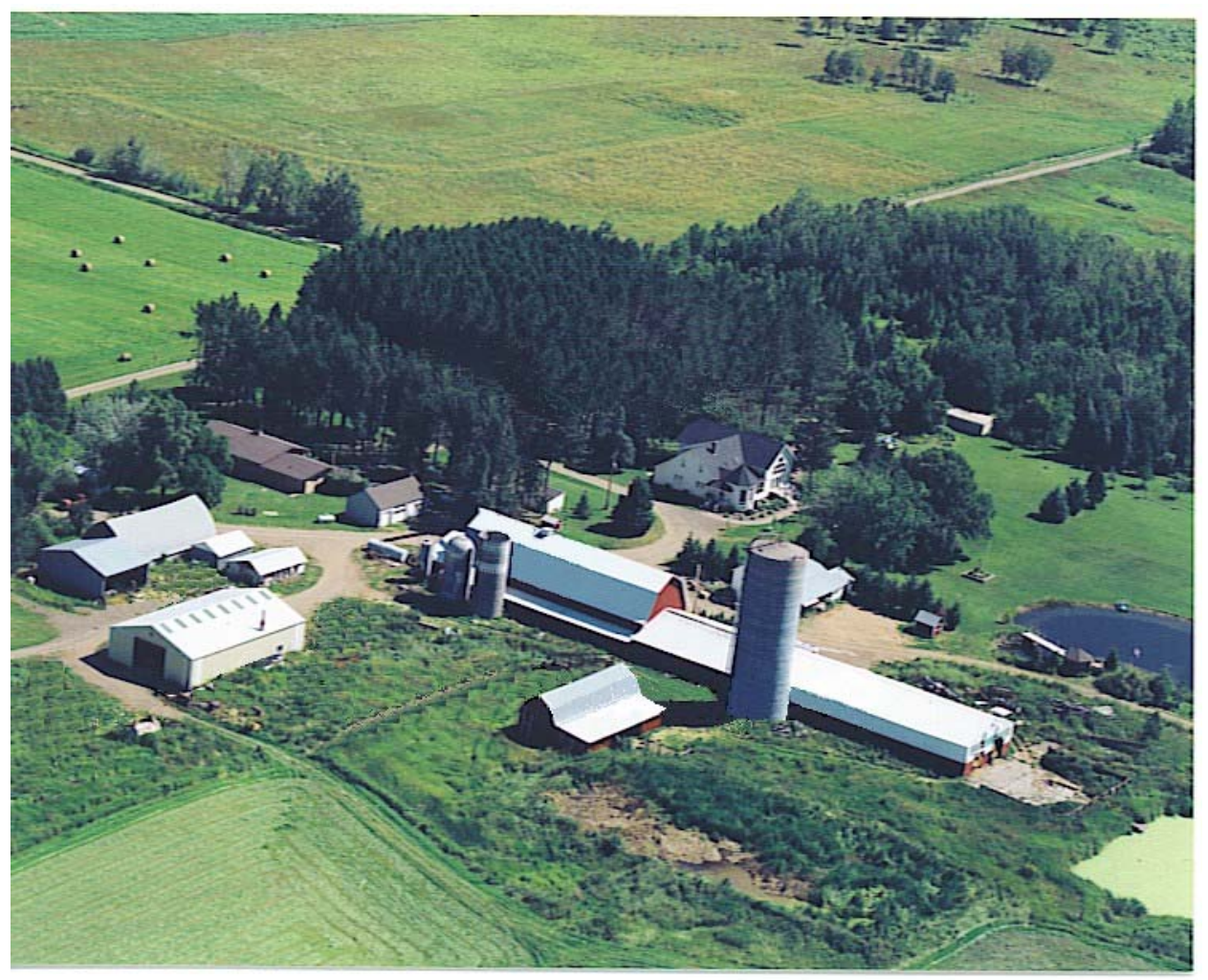

Jamey A. Murray

Graduate Student

Agricultural and Extension Education

Davis College of Agriculture, Forestry, and Consumer Sciences

West Virginia University

Morgantown, WV 26506

Thank you for taking the time to complete this survey 


\section{Farmers Perception of Farmland Preservation}

A. Are you familiar with the West Virginia Voluntary Farmland Protection Act 2000 (WV Code 8-24-72 through 8-24-84)?

a. Yes

b. No (Please proceed with the remainder of the survey and answer as many questions as you can regardless of how much you know about the Farmland Protection Act.)

Instructions: Using the following Likert scale, rate your opinion on each of the farmland preservation issues. Indicate your opinion by circling the letters that best corresponds to your response: SD - Strongly Disagree, MD - Moderately Disagree, SD - Slightly Disagree, SA - Slightly Agree, MA - Moderately Agree, and SA - Strongly Agree.

\begin{tabular}{|l|l|l|l|l|l|l|}
\hline ISSUE & & & & & & \\
& & & & & & \\
\end{tabular}




\begin{tabular}{|c|c|c|c|c|c|c|}
\hline ISSUE & 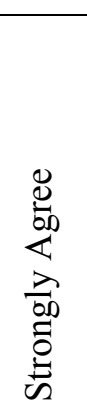 & 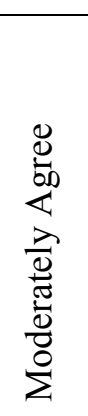 & 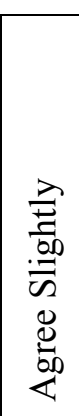 & 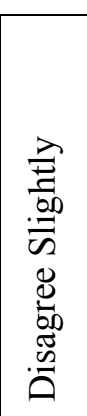 & 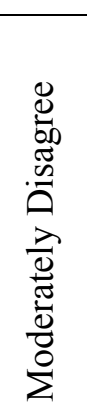 & 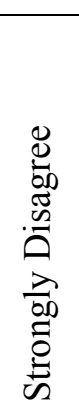 \\
\hline $\begin{array}{l}\text { 7. A Farmland Preservation Program will provide } \\
\text { a good opportunity for landowners in my } \\
\text { county. }\end{array}$ & SA & MA & AS & DS & $\mathrm{MD}$ & SD \\
\hline $\begin{array}{l}\text { 8. A Farmland Preservation Program should be } \\
\text { forever. }\end{array}$ & SA & MA & AS & DS & $\mathrm{MD}$ & SD \\
\hline $\begin{array}{l}\text { 9. The real estate transfer tax is beneficial to my } \\
\text { county. }\end{array}$ & SA & MA & AS & DS & MD & SD \\
\hline $\begin{array}{l}\text { 10. The real estate transfer tax should be used to } \\
\text { fund Farmland Preservation Programs. }\end{array}$ & SA & MA & AS & DS & MD & SD \\
\hline $\begin{array}{l}\text { 11. I would consider including my personal land in } \\
\text { a Farmland Preservation Program. }\end{array}$ & SA & MA & AS & DS & MD & SD \\
\hline $\begin{array}{l}\text { 12. If a Farmland Preservation Program is } \\
\text { implemented in my county, the overall tax base } \\
\text { will not be affected. }\end{array}$ & SA & MA & AS & DS & MD & SD \\
\hline
\end{tabular}

Instructions: Please check the appropriate response to each of the following questions.

13. Has a Farmland Preservation Program been proposed for your county?

a. Yes

b. No

c. Not sure

14. Has a Farmland Preservation Program been implemented in your county?

a. Yes

b. No

c. Not Sure

15. Do you think a Farmland Preservation Program should be included in your county?

a. Yes

b. No 
16. How long has the Farmland Preservation Program been implemented in your county?
a. Less than 1 year
b. 1-2 years
c. 2-3 years
d. 3-4 years
e. 4-5 years
f. 6 or more years
g. Not sure
h. No program exists in my county

17. Are you a member of the farmland preservation board?

a. Yes

b. No

18. Have farmers within your county been informed/educated about the Farmland Preservation Program?
a. Yes
b. No
c. Not sure

19. Has the general public been notified/educated about the program?

a. Yes

b. No

c. Not sure

20. By which methods would you prefer to be informed/educated about the advantages and disadvantages of a Farmland Preservation Program? (Select the top five and rank their effectiveness starting with the most effective (1) and moving to the least effective (5).)

a. Television

b. Radio

c. Newspaper

d. Public Meetings

e. Mail

f. Newsletter

g. Internet

h. Email

i. One on One Conversations

j. Other (please specify) 
21. Who do you think should serve on a farmland preservation board? (Check all that apply)
a. Lawyers
b. County Commissioners
c. Judges
d. Land Surveyors
e. Extension Agents
f. Farmers/Landowners
g. Farm Bureau Members
h. Soil Conservationists
i. Other (please specify)

22. What are the barriers to participating in a Farmland Preservation Program? (Select all that apply)

a. Increases in property taxes

b. Program is forever

c. Application process is time consuming

d. Funding for the program is limited

e. Lack of interest

f. Increases in real estate transfer tax

g. Lack of knowledge

h. Other (please specify)

i. Other (please specify)

j. Other (please specify)

23. What impacts do you believe a Farmland Preservation Program will have on your county 10 years after implementation? (Select all that apply)

a. Increased property taxes

b. Increased real estate transfer taxes

c. Decreased farmland loss

d. The agricultural industry will be stronger

e. Small family farms will be maintained

f. Decreased in tourism

g. Increased in tourism

h. Urban expansion will be controlled

i. Other (please specify)

j. Other (please specify)

k. Other (please specify)

1. Other (please specify)

24. What is your gender?

a. Male

b. Female 
25. Which category best describes your age?

a. $18-20$

b. $21-30$

c. $31-40$

d. $41-50$

e. $51-60$

f. $61-70$

g 71 or older

26. How many years have you been farming?

a. $1-10$

b. $11-20$

c. 21-30

d. 30 or more years

27. How many acres of farmland do you own?
a. $1-25$
b. $26-50$
c. $51-75$
d. $76-100$
e. 100 or more

28. Do you own land that is preserved through the Farmland Preservation Program?
a. Yes
b. No

29. Would you consider placing your land in Farmland Preservation?

a. Yes

b. No

c. Not Sure

30. Are you currently managing the same farmland as previous generations of your family?

a. Yes

b. No

31. What do you foresee happening to your farmland in the future?

a. Passed on to the next generation

b. Sold

c. Placed in Farmland Preservation

d. Developed for residential use

e. Developed for commercial use

f. Other 


\section{Comments:}

If you have questions about the survey, please contact me at: jmurray4@mix.wvu.edu or call (304) 293-4832 x 4482

\section{Thank you for taking the time to complete this survey}


APPENDIX E

Responses to Open Ended Questions 
Question 20: By which methods would you prefer to be informed/educated about the advantages and disadvantages of a Farmland Preservation Program?

Extension Agent

Question 21: Who do you think should serve on a farmland preservation board?

Business

Non-Farmer

Ordinary residents

Agriculture Educators

Agribusiness

Landowners in the county

Question 22: What are the barriers to participating in a Farmland Preservation Program?

Size of farm

Inadequate funding to make a real impact

Will benefit only a few

Not allowing my kids to build on farm

Not allowing me to transfer farm to my kids

Times change

Cooperation of county commission

Developing an efficient program

Pollution

Heirs cannot build their own homes on land

Question 23: What impacts do you believe a Farmland Preservation Program will have on your county 10 years after implementation? 
More green space

Don't Know

Someone else will be telling you what you can and can't do with your land

This will not preserve as much as it will line the pockets of some, then just let good land

grow up

Minimal overall impact

\section{Question 31}

I hope it stays in farm, but believe that would be up to what my family will do. 
VITA

Jamey Murray

Education: August 2009

May 2006

Professional

Experience: August 2006 - May 2007

August 2005 - May 2006

May 2005 - August 2005

May 2006 - August 2006
Masters of Science

Agricultural and

Extension Education

West Virginia University

Morgantown, West Virginia

Bachelors of Science in Agricultural and Environmental Education

West Virginia University

Morgantown, West Virginia

Vista Program Assistant

Davis College of Agriculture,

Forestry and Consumer Sciences

West Virginia University

Morgantown, West Virginia

Teacher Assistant

Division of Agricultural and

Environmental Education

Davis College of Agriculture,

Forestry, and Consumer Sciences

West Virginia University

Morgantown, West Virginia

Summer Intern

United States Department of

Agriculture

Division of Natural Resource

Conservation Service

Gettysburg, Pennsylvania 